\title{
PRIVATIZATION EXPERIENCES IN FRANCE
}

\author{
MiCHEL BERNE \\ GÉRARD POGOREL
}

CESIFO WORKING PAPER NO. 1195

CATEGORY 9: INDUSTRIAL ORGANISATION

MAY 2004

PRESENTED AT CESIFo CONFERENCE ON PRIVATISATION EXPERIENCES IN THE EU NOVEMBER 2003

An electronic version of the paper may be downloaded

- from the SSRN website:

-from the CESifo website: www.CESifo.de 


\title{
PRIVATIZATION EXPERIENCES IN FRANCE
}

\begin{abstract}
France lived through a long period of nationalization until the early 1980 s, when nearly all the largest industrials firms as well as all the banks and public services were state-owned. Since then, a series of privatization moves have caused the state sector to shrink. Public services present a complex situation. For example, after its IPO, the national telecommunications operator France Telecom was simultaneously subjected to the deregulation of the telecom market in the world and to a new type of governance. EDF, the national electricity producer is next in line and should experience the same problems and opportunities.
\end{abstract}

JEL classification: L33, L50, L97.

Keywords: France, privatisation, competition, regulation, utilities.

Michel Berne

Département SGES

9 rue Charles Fourier

F-91011 Evry cedex

France

michel.berne@int-evry.fr
Gérard Pogorel

GET/ENST

Département EGSH

46 Rue Barrault

F-75634 Paris cedex 13

France

gerard.pogorel@enst.fr 


\section{Introduction: Nationalization and privatization in France, an historical perspective}

The approach used in this paper is two-fold. First a general introduction to the specific features of French privatization policies is set out, then their impact is studied using the example of France Telecom, the incumbent telecommunications operator, with additional information about other significant firms. As France does not provide any dramatic examples of privatization policies, the interesting part of the story lies in the change of perspective that has led this country to stop being a champion of nationalization and to manage partially privatized firms within the framework of liberalization in Europe.

\subsection{Nationalization Policies}

Indeed, French privatization cannot be understood without a long historical perspective: before privatization, France has lived through a long period of nationalization and has built at some time a "doctrine" about the coexistence of the private and the public sector. Public services were traditionally provided by state-owned monopolies.

One can list three major periods when private companies have been nationalized in France: - $\quad$ at the end of the XIX ${ }^{\circ}$ century for some railways and the telephone. The PTT were created in 1889 by the merger of the state administration of Posts and Telegraphs and the privately-held Société Générale des Téléphones on the other side. The resulting PTT administration has lived until 1991.

- Before and after World War II, for the railways, the central bank, the energy producers, the major banks and the car manufacturer Renault; some of them are still state-owned in 2003.

- In 1981-1982, the socialist government (F. Mitterrand being President of the Republic) nationalized all the largest industrial companies and banks remaining in private hands. Most of them have returned to the private sector before 2000 .

The rationale behind these various moves can be summarized as follows:

1 - Some private companies were in poor financial health, and/or provided substandard services (railways, telephones, steel-makers, computer manufacturers, etc.).

2 - Some firms were thought to be too powerful or strategic to remain private companies: their resources and policies had a large impact on economic policies as a whole (banks, energy, transportation, defense). So in order to have a free hand for its economic and social policy, the government concluded it had to own all the largest companies in the country. This was especially 
crucial after World War II when the country infrastructure had to be rebuilt as fast as possible, but it also inspired the nationalization policy of 1982. However, the debate between proponents and opponents of nationalization in 1982 looked like "theology" to the respected political commentator André Fontaine (Fontaine, 1981). Fontaine predicted limited impact on industrial firms, but more on banks. Indeed, as Jacques Attali (Attali, 1994), special assistant to President Mitterrand from 1981 to 1991 , put it bluntly much later:

"Had we not nationalized banks, banks would have been extremely hostile to all reforms.

Maybe the Left has not transformed them into allies [...] but we have at least weakened and neutralized a potential "enemy".

We can add that the government wanted to use these firms as examples of well run companies with advanced social policies.

3 - Finally, a special case with Renault: because Louis Renault, then head of the company, had collaborated with the occupying German forces during World War II, his property was seized.

Starting with Colbert, the "mercantilist" finance minister of Louis XIV in the $17^{\text {th }}$ century, French governments have slowly built a doctrine of a "mixed economy" blending powerful public services, large state-owned companies in heavy industries, energy, transportation and finance and small private companies. Nationalization was just one part in a global policy including five-year economic plans, price controls, “export management”, technology management etc. (Cohen, 1992) The peak of this policy can be found during the period when the Socialist Party and their allies ruled France from 1981 to 1986. At that time, the total public sector (central and local government plus state-controlled companies) represented $21 \%$ of production, $23 \%$ of wages earners, $28 \%$ of GDP, $30 \%$ of exports and $49 \%$ of gross capital formation (Mamou 1996).

Table 1 about here

Table 2 about here

\subsection{The case for privatization - major factors}

However, it became clear over time that this situation could not go on forever for four major reasons:

1 - Besides the theoretical critics of state ownership of firms, basically resting on the theory of incentives, the French state behaved as a weak and erratic "shareholder", hesitating between the maximization of short-term financial or political benefits and a "laissez-faire" approach supposed to let the state firms develop as they wished, in spite of the bureaucratic control of their activities. Several severe audits of state management of public firms can be found, most recently a report of 
the National Assembly (Diefenbacher 2003). In particular, the national telecom operator has long suffered from these vagaries (Bonnetblanc 1985; Bertolus 2003). Adverse effects of poor state control can be felt by the firms themselves, by the Treasury as well by other French investors ${ }^{1}$. One radical way to solve the problem was privatization. Another was to better manage state investments: the Ministry of Finance created in 2003 a state agency, Agence des Participations de l'Etat, to bring more consistency and vision to the management of state holdings (Barbier de la Serre 2003; Minefi, 2003). In 1999, the total value of shares detained by the state amounted to $€ 400 \mathrm{bn}^{2}$. The French state is a major player on the Paris Bourse (now called Euronext) ${ }^{3}$.

2 - The co-existence of state-run and private companies (as in the car industry since 1945 or in the telecom industry more recently) is awkward, and could prevent nationalized companies from expanding freely at home and abroad; any expansion by a state-owned firm leads the public sector to grow, even without any new nationalization measure.

3 - Even though they can boast an outstanding technical record (see section 3 for examples), state monopolies suffered from time to time from traditional problems like high prices, low regard for customers, bureaucratic attitude (see Giraud 1987 for the case of telecommunications). They also engaged into uncontrolled and costly expansion policies because of the weakness of government control.

4 - A major liberalization and privatization drive started internationally in the 80 s and France followed the trend. Media provide a good example: even the promoter of the public sector and major architect of nationalization, President Mitterrand, starting in 1982, opened the broadcasting sector to private operators. This paved the way later for the privatization of the largest public TV channel, TF1. Even though European competition policy does not demand privatization, it imposes severe restrictions on government intervention in the economy (like state aids); at the same time, deregulation policies (telecom, electricity, railways etc.) allow new entrants - private companies, that nearly automatically complain about the former state-owned monopoly and lead to difficulties with the European Commission.

\subsection{Privatization timeline}

Privatization in France took place in several phases depending on the following factors:

1 - The outcome of legislative elections is the most crucial; in France, the Prime Minister represents the party winning the legislative elections (National Assembly, dominant part of the Parliament) and sets the political agenda ${ }^{4}$. The center-right parties (led by the RPR ${ }^{5}$ - since 2002 called UMP ${ }^{6}$ ) have initiated the privatization drive in 1986, but are cautious as regards the privatization of public services. The Socialist party (the major component of the political "Left" in France) after the nationalization episode of 1982, has emitted diverging opinions about the management of state 
firms and in 2003, this question is still a matter of internal debate in the party. As stated frankly by Henri Emmannuelli, one of the pillars of the Socialist Party:

"The opinion varies depending on whether we are in the majority or in the opposition." (Le Cour and Macke 2003).

2 - Prices on the Paris Bourse (see Graph 1 for the CAC 40 index over the period 1986-2003) are important as to the timing of privatization, but have a very limited impact on privatization decisions.

3 - European deregulation policies (so far particularly in the Telecom sector, but energy is the next on the list).

4 - Sector evolution like technical innovation, alliances, globalization. The management of public entities may ask the Government to privatize their firm in order to pursue their development plans. For example, Michel Blanc, then CEO of Air France, resigned in 1997 when the then prime Minister L. Jospin refused to privatize the national airline.

The size of the state budget deficit also provides a permanent incentive to privatize state firms as France has constantly experienced budget deficits since 1981. Proceeds from the sales of assets are welcome to finance various types of expenses that would be impossible to fund given the budget situation.

Graph 1 about here

After five years of socialist government, the center-right parties were in power again in 1986-1988 and started dismantling the then enormous state sector. They benefited from favorable conditions on the Paris Bourse, at least until the minor 1997 stock crash. The Socialists came back to power in 1988 with a fragile majority in the National Assembly. They enforced a policy that was then was dubbed "neither-neither" (ni-ni in French): no privatization made by the previous government was overturned, but no further privatization was allowed. Limited operations happened nevertheless. The Socialists lost the general elections in 1993, and more privatization was decided on by the Prime Minister Edouard Balladur. In 1995, Jacques Chirac won the presidential elections as well as the legislative elections and additional privatization took place. In 1997, the president called for legislative elections and lost them to the Socialists. After some hesitation, the new Prime Minister Jospin went on privatizing state firms on a large scale. Finally, in 2002, Jacques Chirac won the presidential elections and the Right won the legislative elections.

Table 3 about here

Table 4 about here 
Since 2002, the center-right government of Jean-Pierre Raffarin has made clear he favors privatizing state-owned companies. In his General Policy Address to the National Assembly in July 2002, the Prime Minister said:

"We have a pragmatic approach to the state's role in the economy. As such, we will analyse capital release and privatisation projects case-by-case, taking particular account of companies' interests and the potential for alliances and development. This policy can only be envisaged over the full length of the term. In general, the state's aim is to withdraw from the competitive sector unless specific strategic interests make this undesirable." (Raffarin 2002).

One can add that the unsatisfactory government budget situation is a strong incentive to sell and raise funds. However, this government has been very pragmatic in his approach:

- selling when favorable conditions appeared (for example, Crédit Lyonnais, sold over a weekend to Crédit Agricole in 2003 after some hectic bidding).

- taking into account the long-term interests of the companies (as in the Air France - KLM merger decided at the end of 2003 - that has lowered the share held by the state below $50 \%$ ).

- and even trying to "re-nationalize" companies in deep trouble: such a rumor circulated regarding France Telecom in 2002 when the operator was close to financial breakdown. Considerable financial aid to France Telecom was given through other means. A bolder move was the attempt to rescue Alstom, the troubled electric and transportation equipment manufacturer in the summer of 2003. The French government wanted to buy $300 \mathrm{M} €$ shares in Alstom. But this plan was not approved by the European authorities and the government had to devise a different plan for Alstom.

\subsection{Privatization income}

The large number of firms sold and their size make privatization a profitable operation for the government. An evaluation commission (Commission des Participations et des Transferts) created in 1986 estimates the value of the companies on sale. The Minister of Economy decides on the actual sale price (higher than the price floor price set by the Commission) and the sale method: sale on the stock market, sale to a single investor or a group of investors by mutual agreement or through an auction.

The funds obtained in the sale are housed in a special account (Compte d'affectation des produits de cession). This account is also used when the state-owned companies need fresh capital and loans, in particular before they are sold. Graph 2 shows the annual balance of this fund. 
According to (Minefi, 2003), the gross privatization income from 1986 to July 2003 amounted to 65.8 bn $€$, used in the following way:

- $\quad € 9$ bn to reduce the public debt (mostly between 1986 and 1988);

- $€ 1.6$ bn allocated to a special pensions fund set up to ease the impact of demographic transition on the French pensions system;

- $€ 50.5$ bn allocated to the firms as equity injection;

- 4.7 bn $€$ for the regular state budget (in the early nineties).

Graph 2 about here

Depending on the methodology used, other figures can be presented. As an example, France Telecom has generated 12.3 bn $€$ of gross privatization income between 1986 and 2003 (excluding dividends, interests on loans etc.). When the state has allowed the firm to benefit from an increase in capital of 9 bn $€$ in 2003, this sum has been provided by a state-owned financial holding called ERAP. ERAP has borrowed money to provide the amount required. This is not, from a formal point of view, an outlay by the state and therefore is not deducted from the gross income given above. Using this methodology, the Ministry of Finance finds that only 6 major firms show a negative balance (gross income minus outlays) over the period 1986-2003: Air France, Bull, Crédit Lyonnais, Société marseillaise de crédit, Thomson and Usinor. All these companies have lived through very difficult times.

As can be expected, different figures have be computed by other sources. Table 5 shows independent estimates from Mauduit (2002).

Table 5 about here

Whatever the computations made, from Graph 1 and 2 and Table 4 we can conclude that until 1997, privatization policies were conducted by the Right only, while the left abstained. After 1997, the Left has adopted a more pragmatic approach and privatized major companies. We will see in below how the IPO of France Telecom played a major role in this policy change. 


\section{Impact of privatization}

\subsection{Changes of ownership}

2.1.1. Principles and procedures

Two very different cases can be distinguished regarding changes of ownership. Some companies were swiftly and totally privatized (the smaller ones or the industrial firms nationalized in 1982), but a large number of state-controlled companies went through a very long and sometimes painful privatization process: after a partial IPO, the state gradually sold additional chunks of shares until its participation became nil or reduced to a "golden share" (action spécifique). In a few extreme cases, this last step has not been possible yet either because of legal problems (as we will see in the case of France Telecom) or because of the poor financial health of the company (as for Bull, the troubled computer firm).

The legal privatization framework includes a mention in the French Constitution:

"The law determines the rules of nationalization of firms and the transfers of ownership of

firms from the public sector to the private sector" (article 34). (Legifrance 1958)

Therefore three acts have been passed, covering the standard cases. One of them, voted in 1986, determines the procedures (JO 1986b) while the two others, voted in 1986 and 1993, list the operations to be conducted (JO 1986a; JO 1993). For the largest companies, a special privatization act is needed to prepare the operation. A government decree is enough for smaller firms.

Moreover, all large public firms have hundreds, sometimes thousands of subsidiaries. Sales, joint-ventures, creations etc. are part of the normal development of businesses: therefore, a special system has been set up to allow normal "respiration" of the public sector. Most subsidiaries of stateowned firms as well as local public services (sociétés d'économie mixtes locales) since 1993, can be sold under two simple declarative procedures (Minefi 2003). From July 1993 to July 2003, 324 sales involving 159,622 employees have been performed under the "respiration system"; from July 2002 to July 2003, 18 sales were performed, involving 2555 employees.

Table 6 about here

\subsubsection{France Telecom}

If we take the case of France Telecom, the full privatization process required three steps. The first one was the transformation of the PTT administration into two para-statal entities - this has been 
done by an act voted on July 2, 1990 (JO 1990a) creating La Poste and France Telecom. A large scale public debate was organized beforehand by the Ministry of PTT to prepare the move (Prévot, 1989). The unions were satisfied by the guarantees offered that the personnel would remain mostly public servants and that no further change was prepared, except for another act voted on December 29, 1990 (JO 1990b) This last act introduced the changes needed by the new European regulatory regime following the 1987 Green Book on telecommunications (Commission 1987). However more changes were soon needed to cope with the decision, taken in 1993 at the European level, to have full competition in 1998 in the telecommunication sector. The French government, pushed by the top management of France Telecom, decided to make an initial public offering (IPO) of the company in 1995. The change of statute was mainly justified by the international ambitions of France Telecom, after several promising deals abroad (Argentina, Mexico, and above all a strategic alliance with Deutsche Telekom and Sprint). However, the IPO was delayed by protests of the trade unions and the many other social problems encountered by the government at that time. In 1995, after the elections, a new CEO was named (Michel Bon) with a clear mandate to manage the change of statute and the IPO. To prepare the introduction of full competition in 1998, a second telecommunications act was passed in 1996 to transpose European directives.

\section{EPIC}

An EPIC (Etablissement public à caractère industriel ou commercial) is a state entity with mixed features. On one side, it belongs to the state system: its mission is defined by law and cannot be easily extended (this is called the "specialty principle"); it cannot default financially as it benefits from state backing; it does not always pay taxes like a normal company; it has a Board nominated by the state and all its main decisions have to be approved a posteriori. On the other side, it conducts quasi-normal commercial operations, can enter partnerships and own subsidiaries. Variations exist in the actual statute of the many EPICs found in France. From 1991 to 1996 France Telecom was a exploitant public (state-owned operator), a special kind of EPIC. (Minefi 1991)

As a companion to this 26 July 1996 telecom regulation act (JO 1996a) another act was also adopted in 1996 transforming the para-statal entity France Telecom into a quasi-standard private company (JO 1996b). Moreover, in 1997, France Telecom paid bn5.7 $€$ to the state as a lump sum to be used to pay the extra costs of the pensions of its retiring civil servants: the government was 
happy to receive funds lowering the budget deficit while France Telecom was happy to get rid of a sizable pension debt looming in the future.

These changes opened the way for the second step in the privatization process, the Initial Public Offering (IPO) of France Telecom in 1997. The IPO was planned for the Spring of 1997 and a lengthy internal communication process took place to overcome the strong opposition from the unions despite the promise of the government that the state would keep control of the firm. But the center-right Juppé government lost the legislative elections at that time and was replaced by the Jospin government (socialist). The new Prime Minister asked for a "social audit" of the whole process (the socialists being traditionally against privatization) but finally gave the green light to the IPO, understanding that the government was unable to finance the development of France Telecom in the new international competitive context (Bertolus 2003 35-70).

The IPO took place in the Fall of 1997 and netted $€ 29$ bn. The state kept $75 \%$ of the capital; 4 million individual shareholders asked 3 times the number of available shares and finally got 10.55 $\%$ of the capital. Financial institutions obtained $11.95 \%$ (they had asked 20 times the number of available shares) and $70 \%$ of the personnel of France Telecom bought $2.5 \%$. A second public offering took place in 1998 and netted $€ 9$ bn.

As shown in Table 7, the percentage of France Telecom owned by the state has not decreased regularly. In 2002-2003, the government had to rescue France Telecom, then in dire financial straits due to its enormous debt (see Section 4 for details). On this occasion, part of the state participation was allocated to a state-owned financial holding company, originally devoted to the oil sector, ERAP. In October 2003, the state held $28.69 \%$ of the capital of France Telecom.

The last step will happen when the state sells its last share of France Telecom. Back in 1997, more than $80 \%$ of France Telecom personnel were civil servants and a decision by Conseil d'Etat, the Government counsel and higher administrative court, had made it clear that civil servants could work in a private company only if (1) the government still held the majority of shares directly or indirectly and (2) the company was in charge of a public service (Conseil d'Etat 1993). France Telecom met the two conditions. However, in 2003 two changes appeared. On one side, the new European telecom regulatory package was enforced demanding that Universal Service be tendered. Therefore, France Telecom could, in theory, lose Universal Service. On top of that, the Raffarin government (center-right) opened the way to a sale of more France Telecom shares, a move designed to fill the state coffers as well a to free France Telecom from government control (useful for the international expansion of the firm). A law was adopted by Parliament at the end of 2003 
(Mer 2003, JO 2004). In a derogatory way, it allows the 104,000 civil servants still working at France Telecom at that time to remain in the company until they retire.

Table 7 about here

\subsection{Who owns the privatized firms?}

One major concern of the French government was to keep control of the companies while selling their capital, or at least to prevent the privatized companies from falling into foreign hands. During the first privatization phase, in 1986-1988, the government tried to set-up stable groups of investors (in French Noyaux durs for "hard core"). This decision generated a long controversy about the choice of these friendly and stable investors; it was modified in 1989 (JO 1989). There was a limited number of potential investors in France, this led to a fairly high level of "consanguinity" between all the groups with the largest banks playing a major role in the process. As shown in Table 6 , the percentage of foreign ownership has nevertheless grown to very high levels for some companies. In an extreme case, in 2003, the Canadian firm Alcan has launched an offer for Pechiney - so the later will not longer be under French management. One can safely conclude that the globalization of business has dealt a fatal blow to any dreams of national independence that might have inspired French governments in the past.

Table 8 about here

Another impact was the creation of a large class of small shareholders, tempted by the initial public offering of blue-chip stocks. As shown in Table 9, the largest groups of private shareholders were to be found in banks, large industrial firms and France Telecom. The France Telecom IPO generated a tremendous interest in the general public, who was severely rocked by the incredible rise and precipitous decline of the price of the share in the later years. Details about the financial performance of privatized companies will be found in Section 4. However, private investors have kept a hearty appetite for shares of privatized companies as proven by the various recent IPOs. (Observatoire, 2003). The staff of privatized companies has also massively bought the shares reserved for them by law (at very sweet prices). But as France Telecom staff members soon understood, it could be a risky investment: they have seen the value of their shares divided by 11 between 2000 and 2002. (de Tricornot and Picquet, 2002).

Table 9 about here 


\subsection{Changes in regulation}

2.3.1. Setting up independent regulators

France does not have a long tradition of independent regulators: direct intervention by the administration was deemed enough to regulate the existing strong monopolies. For example, the central banker, Banque de France, created in 1800 as a private entity, had been nationalized in 1936 but obtained its full independence in 1993 only. With the arrival of new entrants following deregulation in most sectors, new bodies were set up. A good example is provided by the broadcasting regulator CSA which has been preceded by two short-lived and controversial bodies. Most of these regulators are independent regulatory authorities (Conseil d'Etat 2002). But there is at least one special case: in the railway industry, the network has been transferred to Réseau Ferré de France. This is a state company ("EPIC"). It manages the network and regulates rail transport. It receives tolls from the state company, SNCF and any other users. RFF decides on network expansion, subcontracts construction work and pays SNCF for network maintenance.

Table 10 about here

\subsubsection{Autorité de Régulation des Télécommunications and Ministry of Economy} In the focus made on the telecommunications sector, ART provides a good example of the problems encountered. It was set up in 1987, one year only before the sector was fully deregulated, so it has a limited experience; it shares with CSA the regulation of converging services; moreover radio spectrum allocation is decided in a two-stage process supervised by the inter-ministry Agence Nationale des Fréquences (ANFR); finally, it faces a formidable incumbent, France Telecom, formally under the control of the Ministry of Economy, Finance and Industry. As we will show later, France Telecom has embarked on an ambitious development plan following its IPO. This plan has failed and a controversy has risen in 2002 about government control of the company.

Obviously, France Telecom has been able to decide on its own in many instances, but one should stress that government control is weak for a structural reason: as the promoter of competition policy, it cannot closely monitor France Telecom - or it would be accused of ruining competition. (Diefenbacher 2003).

\subsection{Changes in competition}

Privatization does not appear to be a key ingredient in changes in the competitive situation in France. Deregulation is the key factor, and privatization of any state-owned firm can only help as its clears the way for a "normal" competitive situation. It is indeed a very awkward situation when the 
state is at the same time promoting competition and the owner of the largest market player.

Furthermore, the situation is quite different in the network industries and in the other sectors. In the latter case, competition is the normal way to run markets and barriers to entry tend to be lower. In network industries, barriers to entry can be extremely high for economic reasons - the so-called natural monopoly problem, or the related "essential facilities" problem. There could be as well legal reasons such as licensing but the current deregulation process taking place in Europe is slowly eliminating this last obstacle. Therefore, the privatization of a state monopoly will give various results depending on these elements as shown by the contrasted situation of airlines and telecommunications. Until the arrival of low-cost companies in the XXIth century, Air France has kept a strong grip on the French market and all moves to create a viable competitor to the flag carrier have failed, as testified by the attempts of British Airways, Swissair (with Air Lib), as well as several independent companies.

\subsubsection{France Telecom}

On the other hand, France Telecom has steadily lost market share to its competitors: at the end of 2002, it held less than $50 \%$ of the mobile market and $64 \%$ of the long distance market. It keeps 81 $\%$ of the local telecommunications market, but the unbundling of the local loop is progressing fast as shown in Table 11.

Table 11 about here

One can add that an indirect impact on competition comes from privatization. When a firm leaves the state sector, it undergoes a drastic change in its corporate culture, usually becomes more aggressive on the market and more flexible in its management. These points will be further expanded in a later paragraph on the performance of privatized companies.

\section{Sector issues}

Several reasons explain why some sectors have been privatized faster than others:

1 - The existence of competition makes public management very complicated. As explained above, in the case of the car manufacturer Renault, the government was at the same time the owner of the largest car company and was regulating the car industry: any move by the government regarding technical standards, competition policy etc. had conflicting impacts on its two missions; 2 - Some companies had been state-owned in the eighties for a short period only, after 1982. Privatizing them was easier than the public services under public management for decades; 
3 - European deregulation did accelerate privatization schemes: in telecoms and air transport, deregulation has taken place and national companies have been at least partially privatized; deregulation was under way in rail transport, energy and postal services at the end of 2003. No concrete privatization moves have happened early 2004, but they are being contemplated in the electricity and gas sectors;

4 - It is always easier to privatize profitable companies. The Juppé Government had planned to sell the then unprofitable company Thomson for 1 French Franc in 1996: the Privatization Commission refused the decision and it was postponed;

5 - But at the same time, it is more difficult to explain why well-run entities need to be privatized (why change a good system ?). Opponents to the privatization of efficient firms like France Telecom first, and later of EDF stress the risks associated with a change in ownership and management. On the contrary, privatizing poorly-run entities is more readily acceptable; 6 - Strong union presence hinders privatization. The major trade union, Confédération Générale du Travail (CGT), a former close ally of the French Communist Party (PCF), is opposed to privatization in principle. It is very strong in some public companies like the electricity producer EdF. In the recent years a new union (SUD) was created from parts of other unions. SUD is radically opposed to privatization. It is a minor, but very vocal stakeholder in the railways and telecoms.

7 - Finally, timing plays a great role in privatization. Governments decide on a tentative calendar that will be followed - or not, depending on elections outcome stock exchange levels, economic outlook etc. For example, the capital of Snecma, a major aviation equipment manufacturer, was planned to be opened by the Jospin government (before 2002). Finally, the move should be completed in 2004 by the Raffarin government. Poor conditions on the Paris Bourse explain the delay.

Table 12 about here

Table 13 about here

At the end of 2003, state-owned firms can be found in 4 major categories: 1 - Public services. Privatization follows European Union deregulation policies, usually with some delay. The case of EdF, the electricity producer is discussed below. SNCF, the national railways provides a rather decent service, is in very poor financial condition and trade unions are very active: no privatization plans are possible.

2 - Defense and other strategic industries. Privatization or at least transformation of state administrations into standard companies is a must to participate in the construction of the new 
European defense industry. GIAT-Industries produces weapons and armored vehicles. It is a firm since 1990, but its financial problems are such that any further move is impossible. On the contrary, DCN (Direction des Constructions Navales, the former Navy shipyards) has been transformed into a firm in 2003 and it is in good shape. SNECMA, a major aviation engine producer is on track for privatization.

3 - TV and radio. Back in 1987, the first state channel, TF1, had been privatized and sold to the Bouygues group. It is still the market leader with about one third of the total audience and one half of the national TV market. France Télévisions is the holding company managing the remaining state TV channels, notably France 2 and France 3. Even though rumors regularly surface as to the privatization of one or several of these channels, the government had no official plans at the end of 2003. TF1 had lodged a complaint in 1993 with the European Commission about some state aids to the public TV sector, but the Commission, in 2003 has approved the aids.

4 - Miscellaneous firms: Charbonnages de France (coal mines, closing down), Française des jeux (lottery), toll highways etc.

\section{1. $E d F$}

An interesting example of the difficulties of privatization policies for public services is given by the situation of EdF at the end of 2003. On one side, European deregulation policy means that competition has arrived on the French market. The French government is fighting to slow the move at the European level. On top of that, EdF, as an EPIC, benefits from the financial guarantee from the state, a clear advantage anytime it has to borrow money. From a fiscal point of view, it also benefits from special possibilities. As a result, in 2003 the European Commission believed that EdF benefited from an undue competitive advantage and it has declared its intention to ask the operator to pay back to the state more than $€ 1$ bn (mostly unpaid taxes) and to press for a change of statute. On the other side, EdF would like to be in a good shape when competition becomes stronger: supply of other energies, reform of the specific pension plan, job cuts. But it is prevented by law from expanding outside of the electricity sector and the main trade union, CGT, has blocked a change in the specific pension plans of EdF-GdF employees in early 2003. So both the management of the firm and the French government plan a change of statute and a slow move to competition, a policy that would solve most of the problems of EdF. However, CGT, the major trade union in EdF, is totally opposed to any change of statute. They have called for a national debate on energy policy to support their views. 


\section{Performance measures}

It is extremely difficult to give clear and objective performance measures for French privatization. However, we will study three major areas for performance: prices, productivity/cost structure and finance.

\subsection{Prices}

In this section, we will concentrate on prices for public services. In competitive areas, like cars, banks etc. prices are market-oriented and price controls are very limited. The situation is very different for public services as they have to get their tariffs approved by the relevant ministries: La Poste has to beg to increase postage stamps prices; EdF has to do the same for electricity tariffs. An interesting situation happens when the firm is partly privatized and operates in a partly competitive environment.

If we look at the emblematic case of France Telecom again, we can see its retail prices decreasing in general and significant marketing efforts taking place (ART 2003; France Telecom 2003a). These moves follow a complex tariff "rebalancing" strategy where local call prices and subscription fees increase while long distance call price decrease as shown in Table 14. It would be very difficult to assume that these results are due to privatization of the national operator. More likely, deregulation in the telecom sector and competition from new entrants explain most of the changes. Moreover, France Telecom (as all other state companies) has to get its main prices approved by the Ministers in charge of Telecommunications and the Economy. From 1997 to 2000, a minimum decrease in prices had been imposed by the Ministry of Economy (- $9 \%$ per year in 1997-1998 and - $4.5 \%$ per year in 1999-2000; these figures apply to a selected basket of basic services. The required decrease in much larger than inflation rates). On top of that, France Telecom has to submit most of its price changes to ART. The opinion of ART is public, but not binding. For example, France Telecom submitted 108 tariff decisions to ART in 2002 for approval, resulting in 64 favorable and 17 unfavorable recommendations (ART 2003). ART is especially careful about predatory pricing by France Telecom, so that it might not approve of too low tariffs. In some well publicized instances, France Telecom got the Ministers to approve very low tariffs despite negative opinions from ART, but these tariffs decisions were eventually cancelled when the competitors complained. Therefore France Telecom is walking on a tightrope: if its prices are too high, it will lose market share; if its prices are too low, they will not be approved. Quality of service has not changed significantly since privatization and, so far, has not been an issue for regulators. The only exception has been customer relations for the whole French mobile sector. 
Table 14 about here

Regarding the highly sensitive issue of interconnection prices, France Telecom, operator with significant market power (SMP), has to publish a Price List (Catalogue d'interconnexion) every year since 1997 and to get it approved by ART. The interest of France Telecom is to squeeze its competitors between high interconnection prices and low retail prices: therefore every Fall a battle starts between ART and the incumbent ${ }^{7}$. As table 15 shows, interconnection prices have significantly decreased thanks to this annual review system. However, tariffs are only one part of the problem, as France Telecom can also use many other tactics to delay or make it more difficult for its competitors to obtain interconnection when they want it and how they want it ${ }^{8}$.

Table 15 about here

\subsection{Productivity and cost structure}

Privatization introduces changes in cost structures for a number of reasons :

1 - Starting and stopping activities is easier. International expansion is also easier. In the case of France Telecom, a few years after privatization the firm has been completely transformed, with a tremendous international expansion;

2 - There is also more flexibility as regards human resources management in all its components : hiring, compensation, promotion ${ }^{9}$;

3 - After privatization, specific tax systems disappear (usually leading to higher taxes).

Table 16 about here

\subsubsection{France Telecom : cost structures}

Comparing selected figures for France Telecom is not easy because of its transformation from a national to a global company, and also because of many changes in accounting methods during the period studied. However, several facts clearly appear from Table 16 comparing the 1996 and 2002 situations:

1 - On the whole, personnel costs have decreased in percentage of sales; however, this is the result of many changes as explained in the next paragraph.

2 - Commercial costs have increased. France Telecom does not always publish details about these costs, but they always show (except in 2002) a significant growth linked to the development of the mobile and internet sector in a competitive environment. In particular, they have shot up from 5.2 to 7.3 billion euros between 1999 and 2000. The percentage of administrative costs compared to sales, 
as far as it can be assessed from the figures provided by France Telecom, has been kept at its preprivatization level.

$3-\mathrm{R} \& \mathrm{D}$ costs have been drastically cut, as discussed later;

4 - Income tax is difficult to figure out in such a diversified group. However, France Telecom has published detailed figures in 1998 for other taxes, such as local taxes. After the end of its specific regime, the 1997 IPO has cost France Telecom more than 300 million euros in additional taxes in France (mostly local taxes, excluding income tax) in that year.

So as a conclusion it is difficult to disentangle the impact of growth, international expansion, competition and changes in accounting methods. But it is clear that deregulation has had a major impact on marketing and commercial costs, while privatization has had relatively minors impacts on $R \& D$ costs and tatxes

Table 17 about here.

4.2.2. France Telecom : personnel costs and labor productivity If we look at the figures of France Telecom in France as shown in Table 17, the number of employees has decreased from 160,700 to 141,100 between 1996 and 2002 while the sales per employee increased from $138,000 €$ in 1996 to $194,000 €$ in 2002. This ratio increased on average $9.4 \%$ per year, well above inflation levels (about $1.5 \%$ per year over the period), and well above changes in output.

Graph 3 about here.

Indeed, as shown in Graph 3, labor productivity has grown a great deal. In 1997, each employee of France Telecom had to care for 207 main lines and 10 mobile lines. In 2002, (s)he had to care for 241 fixed lines, plus 136 mobile lines and 28 internet customers.

Many attempts have been made to give a more precise vision of productivity changes, using DEA or similar methods. The results obtained depend on the quality of the figures and the methods used. Using DEA and statistics provided by OECD, France Telecom appeared to be $85 \%$ "efficient" in 1998 compared to the best European telecommunications operators (Pentzaropoulos and Giokas, 2002). However, efforts by the authors to replicate and enlarge these results using more recent figures have failed due to the absence of consistent data on a national basis in the latest Communications Outlook (OECD 2003).

Privatization is only one cause of this increase in labor productivity, the two main ones being the development of new services (like mobiles) and the age structure: in France, France 
Telecom has rather old employees (the average age was 44.4 years in 2002), mostly civil servants hired in the seventies and eighties. Starting in 1996, a very large number of employees have retired, with additional incentives provided for early retirement (22,000 early retirees between 1996 and 2002). Hiring new employees has followed a stop-and-go process.

Before 1992, most employees belonged to a civil service "rank", linked to the competitive exam they had passed, but with a tenuous link to the job they held. This archaic system was then replaced by standard job descriptions and promotion systems (leading to an average $7 \%$ increase in wages). Increased competition and technological progress also forced redeployments in the staff structure. For example, in 2002, 9500 employees have been retrained and mostly transferred to customer relations, information systems and multimedia (France Telecom 2003a, France Telecom 2003b). Full privatization should make these changes easier to implement, but they are feared by trade unions.

Finally, privatization made it easier to give additional compensation to the top management of the firm. As expected in a former state administration, salaries were modest for executives and of course, no stock options were available. The three largest subsidiaries of France Telecom, Orange (mobile), Equant (data) and Wanadoo (Internet) have set up various stock-options plans representing respectively $2.3,3$ and $2 \%$ of the capital of the firms in 2002 . Regarding the compensation of the Chief Executive Officer, while Michel Bon (a former high civil servant, graduated from ENA) got around $€ 0.37$ million per year, his successor Thierry Breton (an electrical engineer, formerly CEO of Thomson) obtained $€ 1.25$ million in 2002.

\subsection{Innovation}

French public services have long had a reputation for innovation and technical prowess ${ }^{10}$. All these innovations were possible because tariffs were set by the state and were based on large-scale crosssubsidies between services, at least during the launch of the new services or production tools. European regulation, as it opens public services to competition, prohibits cross-subsidies from regulated to unregulated activities as detrimental to competition. Moreover, the state had a longterm view of technical innovation and financial performance so that pay-back periods could be long. In privatized firms, the private shareholders are more impatient about financial rewards, less enthusiastic about technical innovation (Munari 2002) and unable to deal with social and political controversies (as EdF with nuclear energy, dealing with environmental issues).

The case of France Telecom, again, provides an interesting insight. France had had major successes in the seventies in the development of digital switching but also of videotex ${ }^{11}$ (Berne 1997). A less successful, and very costly venture, was decided in cable television in 1982 (Plan Cable). Most of these innovations came from the renowned research center, CNET, (Centre 
National d'Etudes des Télécommunications), founded in 1944 as a national research institution dealing with fundamental research coupled to a traditional operator R\&D center. Following the IPO of France Telecom, CNET has been renamed France Telecom R\&D and completely refocused on internal needs, mainly for the development of new services (France Telecom 2003a). Costs figures for $R \& D$ are provided in Table 16 and show a steep decline as a percentage of sales.

\subsection{Finance}

Financial indicators, like profits, debt ratios and stock prices, provide another set of measures of performance. Again, methodological reasons could flaw the results. As public firms are only privatized when they are profitable, one has to be very cautious about financial results. As shown in the annual report on state firms published by the Ministry of finance, (Minefi 2003), the financial health of the public sector is poor, but now that the government has privatized nearly all the profitable companies, it is mostly stuck with the unprofitable ones. One very positive impact of the privatization process for the firms is that it forces the government to make them profitable (debt reduction, fresh capital, restructuring). Thomson, Air France, Usinor, Crédit Lyonnais have all gone through very difficult times: yet, after some painful years, they have been privatized as soon as they were in good shape and since then (at least until 2003) they have developed normally ${ }^{12}$. Share prices incorporate both general trends on the stock exchange and the situation of each company: from Table 18, one can see that the results are quite mixed, sometimes very disappointing when the company is in deep trouble like Bull. But investors are normally eager to buy shares of privatized groups (Observatoire 2003).

Table 18 about here

Table 19 about here

\subsubsection{France Telecom}

Again, the case of France Telecom is interesting as shown in Table 16 and Graph 3. After its IPO, France Telecom expanded very fast, particularly abroad and in new sectors (mobile, internet, television). When it bought Orange from Vodafone in 2000 at a price of $€ 43.2 \mathrm{bn}, 80 \%$ were paid in cash as issuing new stock would have lowered the share of the state below $50 \%$, a move forbidden by law. France Telecom had to borrow massively for this purchase and those following, including the subsequent $\mathrm{UMTS}^{13}$ auctions. Even though overall operational results were quite acceptable at group level, some of these purchases failed to produce financial returns (for example, the purchase of MobilCom and its UMTS license in Germany), and servicing the debt was nearly impossible. At the same time, issuing new stock was doomed to fail because of the low level of 
stock prices, due to the economic crisis and the telecom bust. The rescue plan devised in 2002 called for $€ 15$ bn of fresh money (€9 bn being provided by the state through ERAP, as explained earlier), debt refinancing of $€ 15$ bn and $€ 15$ bn of savings. The first of these three measures is being investigated in 2003 by the European Commission as a possible infringement of the regulation of state aid.

As regards stock prices, the introduction price for France Telecom shares was $€ 24.03$ and after one trading day it was up to $€ 31.5$; the share peaked at $€ 219$ on March $2^{\text {nd }}, 2000$, then fell to an all-time low of $€ 6.94$ on September $30^{\text {th }}, 2002$. In October 2003 the price was around $€ 21$. The IPOs of Orange and Wanadoo, the two major subsidiaries of France Telecom have not fared better as shown in Table 18.

Graph 4 about here

\section{Conclusions}

\subsection{The changing role of ideology}

The privatization process in France has been heavily loaded in terms of ideology, as had been the case for nationalization itself. The reluctance to privatization had been especially high due to the combination of three political ideologies.

- The Socialist ideology states that "people" or state-ownership are in all cases superior to private ownership.

- The "Dirigiste" (Colbertiste), Bonapartist, and Gaullist tradition, highlights the superior knowledge and vision of the state.

- A Christian inspired Social Doctrine advocates public property in the name of the public good and social solidarity.

This combination resulted not only in the above-mentioned nationalization, but in provisions for "public ownership" to be written down in the 1946 Constitution, as the Government coalition was composed of those three political forces. Until the early 1980s, this combination had remained prevalent in terms of popular support. The radical changeover in ideology and reality in the United States and the United Kingdom did induce, but with some delay, changes in French political doctrines. It combined with the disastrous economic situation which followed the phase of nationalizations performed by the "Union of the Left" Coalition (1981-1986) to pave the way for the protracted, and not yet finalized privatization process. 


\subsection{Perception of privatization policies}

Privatisations are now a widely accepted in principle. However, Unions and social forces are often fighting successfully to oppose them as much as they can, in order to preserve special workers and social conditions in the public sector. It often takes heralding imperious "strategic" moves, like in the Air France KLM merger case, to assuage this reluctance.

It has to be said that the show of exuberance, and reluctance to comply to the governance and information transparency rules they preach, given by the blue ribbon world corporation, has not helped in promoting the image of private corporations in the most recent period.

\subsection{Lesson to be learned?}

The implementation of sound governance rules for the private sector seems to have to go hand in hand with the promotion of the privatization process. The succeeding French governments have learnt the hard way that privatization is a slow process and that one should pay as much attention to corporate governance of partially privatized firms as to privatization moves. As an example, the IPO of France Telecom was a resounding success in 1997; the results of the company were disastrous in 2001 and 2002, and not only because of the burst of the telecom bubble. Another sad example is provided by the computer manufacturer Bull: the state is unable to bring the firm back to profit, despite massive injections of public money (much disliked by the European Commission, as expected).

\subsection{Reaction to $E U$ directives}

EU directives have played a very important role in the evolution of economic ideologies and realities. In many cases, French governments have taken advantage of them to promote internal policies they actually supported without daring saying so. We know no directive can be taken without the explicit agreement of member countries Governments. "Brussels constraining demands", however, have often been invoked by French governments as imposing upon them to take not-so-popular or unpopular measures and decisions. It is a well established principle that European policy is neutral as regards the ownership of firms. However, European policy promotes competition in most sectors. These changes have deep impacts on state firms. Actually, they cannot survive in the new, deregulated, environment without drastic changes. Probably, privatization is the only way for them to meet the challenges of deregulation. After France Telecom and Air France, the government has decided the IPO of EdF and GdF. After France Telecom again, EdF will be a test bed for the success of privatization process: a vital service, a well-run company, sensitive technologies, huge investments in the long-term, deregulation constraints. 


\section{NOTES}

1. In the case of a large, partly state-owned company listed on the stock exchange, any poor performance will have two impacts : on stock prices indexes and on financing conditions.

2. On Sept. 30, 2002, it was down to $€ 17$ bn and on Sept. 9, 2003, it was up to $€ 40 \mathrm{bn}$. Changes in the market value of France Telecom explain most of these enormous changes. See Section 4 for details.

3. Not on a day-to-day basis, but its assets are still massive and any move will have an impact on the market.

4. The Prime Minister has to share part of his power with the President of the Republic, elected in separate presidential elections. But for privatization matters, the Prime Minister decides.

5. Rassemblement pour la République.

6. Union pour un Mouvement Populaire.

7 The European Commission has published a directive on the topic, as well as benchmarks.

8. not all central exchanges are opened to interconnection, for example.

9. Besides productivity and costs, privatization challenges the traditional management of human resources. One should note that a large variety of cases exist amongst state-owned public services. Most of these entities used special statutes for their employees and managed them in a very bureaucratic way. After privatization, they have followed standard HR policies for private firms. A second major change deals with the choice and compensation of CEOs and top managers, again following standard business practice.

10. To name a few examples, EdF has conducted an outstanding program in nuclear energy; rail transport has been transformed by the introduction the TGV high speed train by SNCF and Air France has, jointly with British Airways, operated the supersonic Concorde plane.

11. With 7 million Minitel terminals and around 26000 services in 1995 at the peak of the system.

12. Out of the 1000 largest firms in the world (listed by Business Week by market value in May 2003), 48 firms were French. There were 23 privatized firms in the list. Amongst them, with their world rank: Total (24), France Telecom (57), BNP (74), Vivendi (186), Saint-Gobain (291) Alcatel (338), TF1 (617), Thales (756) etc. (Business Week 2003)

13. Universal Mobile Telecommunications System, the European version of the third mobile generation. 


\section{REFERENCES}

Attali J. 1994, Les nationalisations ont sauvé notre industrie, Capital Paris: № 35, August 1994, 116-117.

ART 2003. Rapport public d'activité 2002, Paris: Autorité de Régulation des Télécommunications, 9.

Baert D. 2000. Comptes spéciaux du Trésor et entreprises publiques, Annexe $\mathrm{N}^{\circ} 43$, Rapport sur le projet de loi de finances pour 2001, Paris: Assemblée nationale, October 2003.

Barbier de la Serre 2003. L'Etat actionnaire et le gouvernement des entreprises publiques, Paris: Ministère de l'Economie, des finances et de l'industrie, 24 February 2003.

Berne M. 1997. French lessons: the minitel case, in: The social shaping of information superhighways, Kubicek H, Dutton W.H. and Williams R (editors). New York: Saint Martin's Press.

Bertolus J.J., Cedro J.M. and T. Del Jesus 2003. Qui a ruiné France Telecom ? Paris: Hachette, 3570.

Borde D. and M.C. Dang-Tran 1997. Legal aspects of the French privatization program: review of the Pechiney privatization as a practical case, Journal of International Affairs, New York:Winter 1997, Vol. 50. Issue 2, 519-529.

Bonnetblanc G. 1985. Les télécommunications françaises : quel statut pour quelle entreprise, Paris: La documentation française, Collection scientifique et technique des télécommunications.

Bureau D. 1997, La gestion des entreprises publiques, Document de travail N 97-5, Paris:

Ministère de l'économie, des finances et de l'industrie.

Business Week 2003. The Global 1000, Business Week, New York: July 142003.

Chabanas N.and E. Vergeau 1996, Nationalisations et privatisations depuis 50 ans, INSEE Première 440, Paris: INSEE.

Cohen E. 1992, Le colbertisme "high-tech”, Paris: Pluriel.

Conseil d'Etat 1993. Avis $n^{\circ} 355255$ du 18 novembre 1993, Paris: Conseil d'Etat.

Conseil d'Etat 2002. Rapport public 2001, Les autorités administratives indépendantes, Paris:

Conseil d'Etat.

De Tricornot and Piquet 2002. Les actionnaires salariés ont perdu $29 \%$ de leurs avoirs en 2002, Le Monde, Paris: 4 October 2002.

Curien N. 2000. Economie des réseaux, Paris: La découverte.

Curien N. and Gensollen M. 1992. Economie des télécommunications, Paris: ENSPTT/Economica; 
Dassler T. Parker D. and D.S. Saal 2002. Economic performance in European telecommunications, 1978-1998: a comparative study, European Business Review Bradford:2002, Vol. 14, Issue 3, 194 209.

Diefenbacher M. 2003. Rapport de la Commission d'enquête sur la gestion des entreprises publiques afin d'améliorer le système de prise de décision, (Commission "Douste-Blazy"), Paris: Assemblée nationale, July 2003.

Ducourtieux C. 2003. La France s'ouvre de plus en plus aux fonds anglo-saxons, Le Monde, Paris: 29 July 2003.

Durant R.F. and J.S. Legge 2002. Politics, public opinion and privatization in France : assessing the calculus of consent for market reforms, Public administration review, Washington: May/June 2002, Vol. 62. Issue 3 307-323.

European Commission, 1987. Green Book on the development of the common market of telecommunications services and equipment, Brussels: European Commission.

European Commission 2003. Green paper on services of general interest, Brussels: European Commission COM(2003)270

Figaro 2003. Le Figaro, économie, Le grand bal des privatisations continue d'animer le marché; Paris: 20 November 2003.

Flores N. 1994. Steady does it : Balladur reforms the French economy, Harvard International Review, Cambridge:Summer 1994, Vol. 16, Issue 3.

Fontaine A. 1981. La querelle des nationalisations, Le Monde, 15 novembre 1981, as reported in: $L a$ Cinquième République, Paris: Le Monde, 1995, pp. 127-128.

France Telecom 2003a. Rapport d'activité 2002, Paris: France Telecom.

France Telecom 2003b, Bilan social 2002, Paris: France Telecom.

Giraud C. 1987. Bureaucratie et changement. Le cas de l'administration des télécommunications, Paris: L'Harmattan.

INSEE, 1999. Tableaux de l'économie française 1999-2000, Paris: INSEE.

JO 1986a. Loi n 86-912 du 6 août 1986 (dite Loi de privatisation), Journal Officiel de la République Française Paris.

JO 1986b. Loi n 86-793 du 2 juillet 1986, Journal Officiel de la République Française Paris. JO-1989 Loi n89-465 du 10 juillet 1989 (dite Loi de "dénoyautage"), Journal Officiel de la République Française, Paris.

JO 1990a Loi n 90-568 du 2 juillet 1990 relative à l'organisation du service public de la poste et des télécommunications, Journal Officiel de la République Française, Paris:157: 8 July 1990. 
JO 1990b Loi n 90-1170 sur la réglementation des télécommunications, Journal Officiel de la République Française, Paris: 303: 30 December 1990.

JO 1993 Loi n 93-923 du 19 juillet 1993 dite "Loi de privatisation", Journal Officiel de la République Française, Paris: 166: 21 July 1993.

JO 1996a. Loi n 96-659 du 26 juillet 1996 de réglementation des télécommunications, Journal Officiel de la République Française, Paris:174: 27 July 1996.

JO 1996b. Loi n 96-660 du 26 juillet 1996 relative à l'entreprise nationale France Télécom, Journal Officiel de la République Française, Paris: 174: 27 July 1996.

JO 2004. Loi n 2003-1365 du 31 décembre 2003 relative aux obligations de service public des télécommunications et à France Télécom, Journal Officiel de la République Française, Paris: 1: 1 January 2004.

Larcher G. 1996, L'avenir de France Télécom : un défi national, Rapport d'information du Sénat $n^{\circ}$ 260, Paris: Sénat.

Le Cœur P. and G. Macke, France Telecom: les députés autorisent le gouvernement à engager la privatisation, Le Monde, Paris: 7 December 2003.

Legifrance 1958. Constitution de la République Française, available on the World Wide Web at: $<\underline{\text { http://www.legifrance.gouv.fr }}>$.

Loiseau H. 2002. 1985-2000 : Quinze années de mutation du secteur public d'entreprises, INSEE Première no. 860, Paris: INSEE, juillet 2002.

Mamou Y. 1996. La saga des privatisations, Le Monde, Paris:19 November 1996.

Mauduit L. 2002. En France les privatisations ont rapporté 70 milliards d'euros, Le Monde, Paris: 9 April 2002.

Minefi 1991. Les grands principes de l'EPN, available from the World Wide Web:

$<$ hppt://www.finances.gouv.fr/reglementation/instructions_comptables/M91>.

Minefi 2003. L'Etat actionnaire, Rapport 2003, Projet de loi de finances pour 2004, Paris:

Ministère de l'économie, des finances et de l'industrie.

Munari F. The effects of privatization on corporate R\&D units : Evidence from Italy and France, R\&D Management, Oxford: June 2002, Vol. 32, Issue 3 223-232.

Observatoire 2003. Observatoire des privatisations / $1^{\text {ère }}$ vague, 2003, Paris: TNS SOFRES Finance, available from World Wide Web: $<\underline{\text { http://www.tns- }}$ sofres.com/etudes/comfi/080403 privatisation.htm>.

OECD 2003. Communications Outlook, Paris: OECD.

Orange M. and A.M. Rocco 1999. Nationalisations-privatisations : l'Etat gagnant, Le Monde, Paris: 17 juillet 1999. 
Pentzaropoulos G.C. and D.I. Giokas 2002. Comparing the operational efficiency of the main European telecommunications organizations: A quantitative analysis, Telecommunications Policy, 26, no. 11 (December 2002): 595-606.

Prévot, H.1989. Rapport de synthèse remis par Hubert Prévot à Paul Quilès, Ministre des Postes, des Télécommunications et de l'Espace, Paris: Ministère des Postes, des télécommunications et de l'Espace.

Raffarin J.P. 2002. General Policy Address, July 3, 2002, available from World Wide Web: $<\mathrm{http}$ ://www.premier-ministre.gouv.fr $>$.

Mer F. 2003. Projet de loi relatif aux obligations de service public des télécommunications et à France Télécom, available on the World Wide Web : <http:www.senat.fr/dossierleg/pj102421.html>.

Suard P. 2002. L'envol saboté d'Alcatel-Alsthom, Paris: France-Empire.

Tribune 2003. dossier spécial privatisations, La Tribune de l'économie, Paris: 15 to 19 September 2003. 
Graph 1 - Stock market index and gross government income

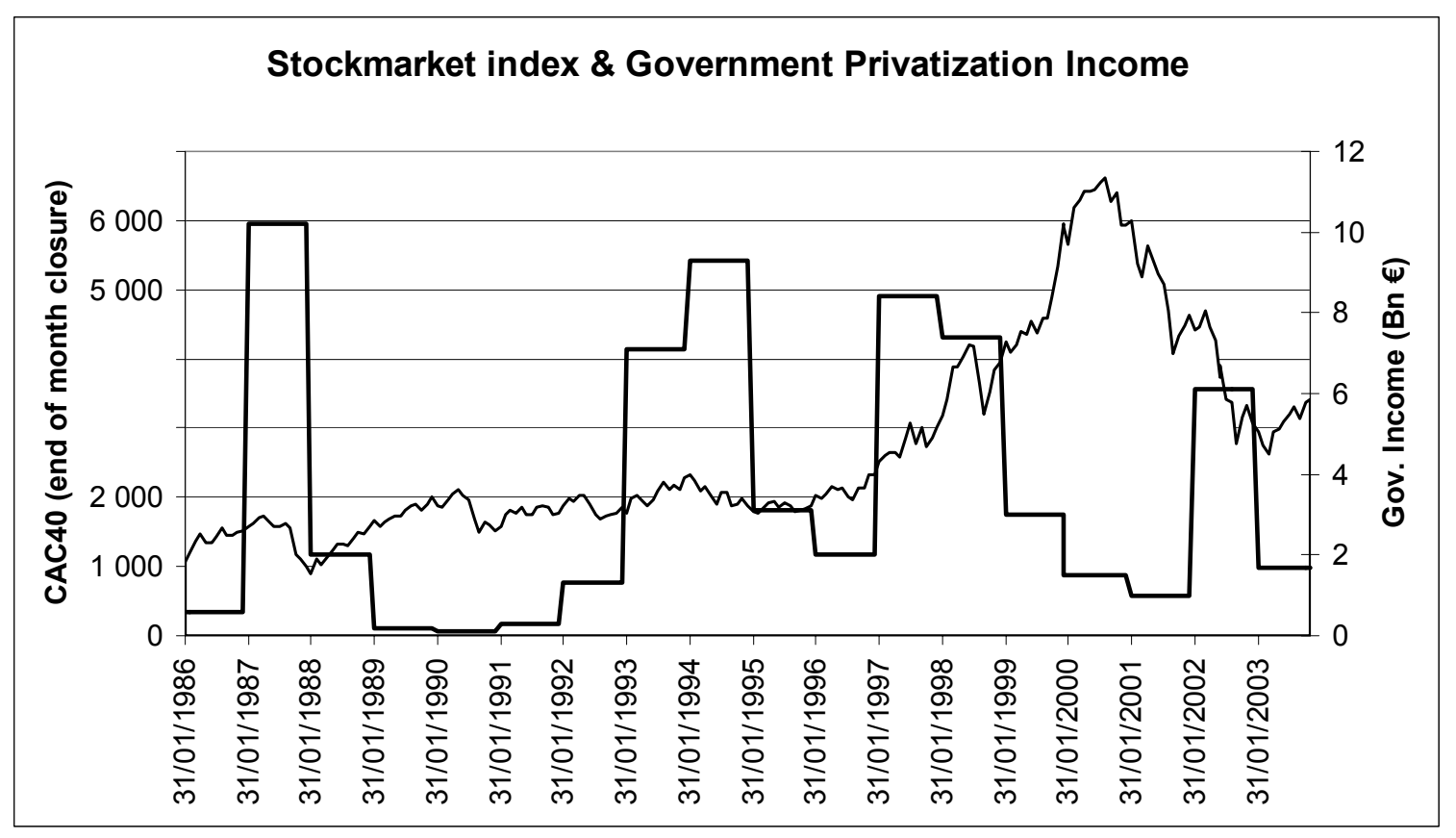

Note: The CAC40 was initiated on 1/1/88; for earlier dates, a "rebuilt" index found at www.bnains.org has been used.

Source: Minefi, 2003 
Graph 2 - Privatization gross income and public sector outlays

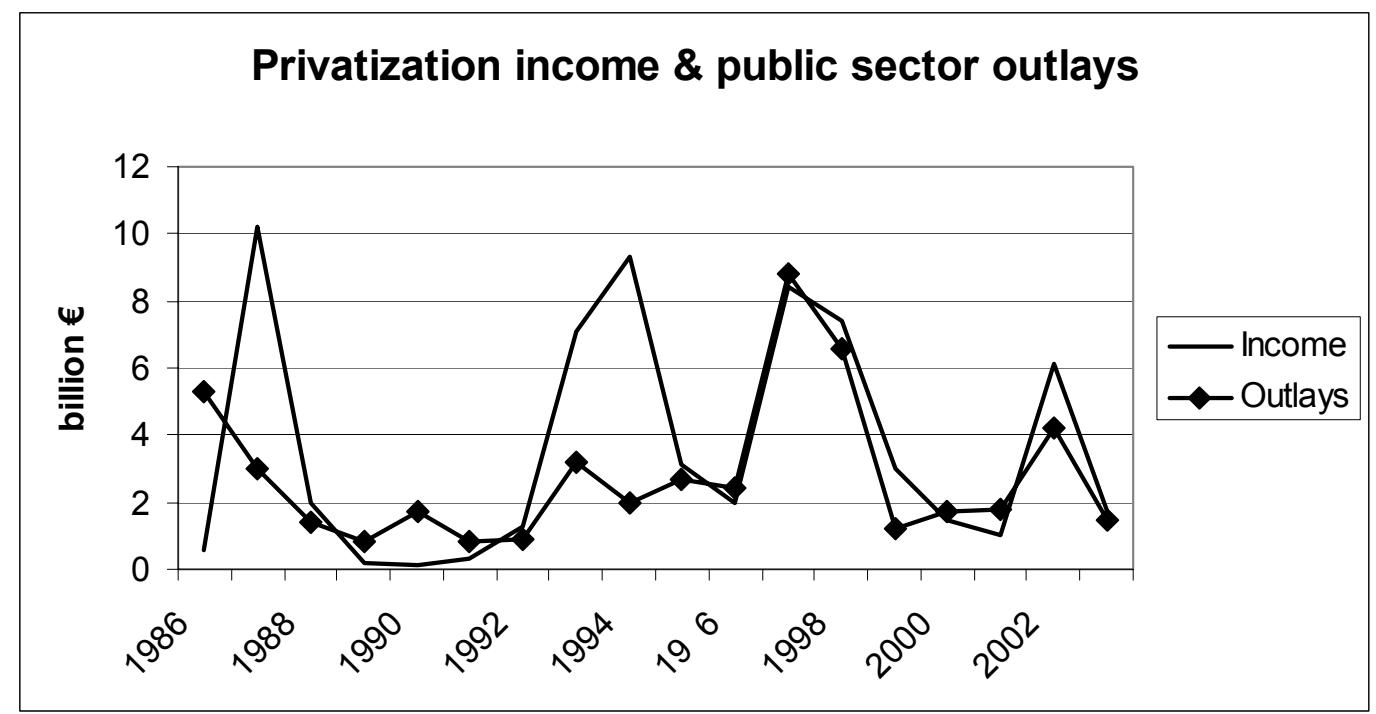

Source: Minefi 2003 
Graph 3 - Labor productivity : France Telecom in France

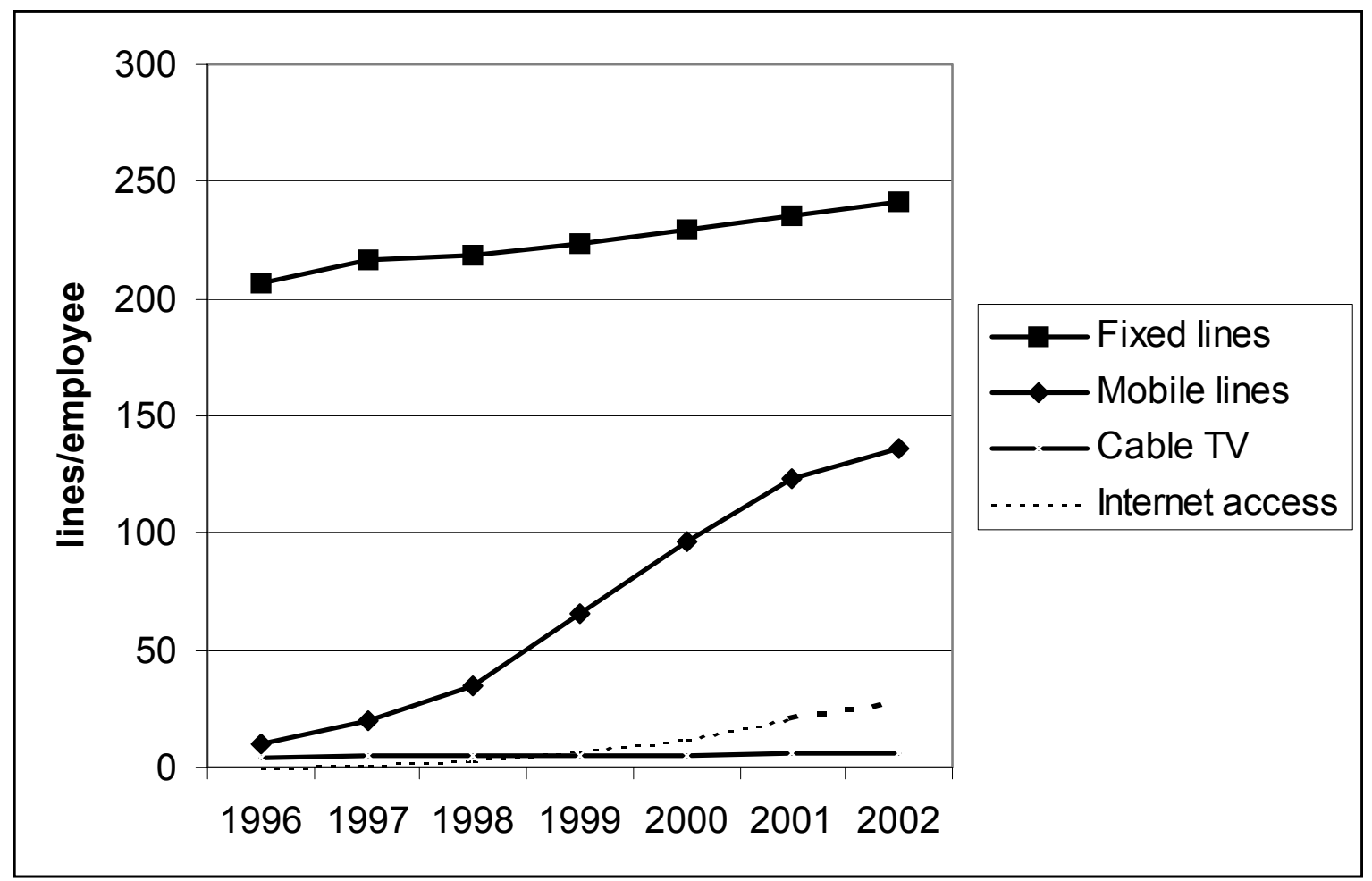

Source : France Telecom Annual Reports 
Graph 4 - France Telecom share price on the Paris Bourse (Euronext)

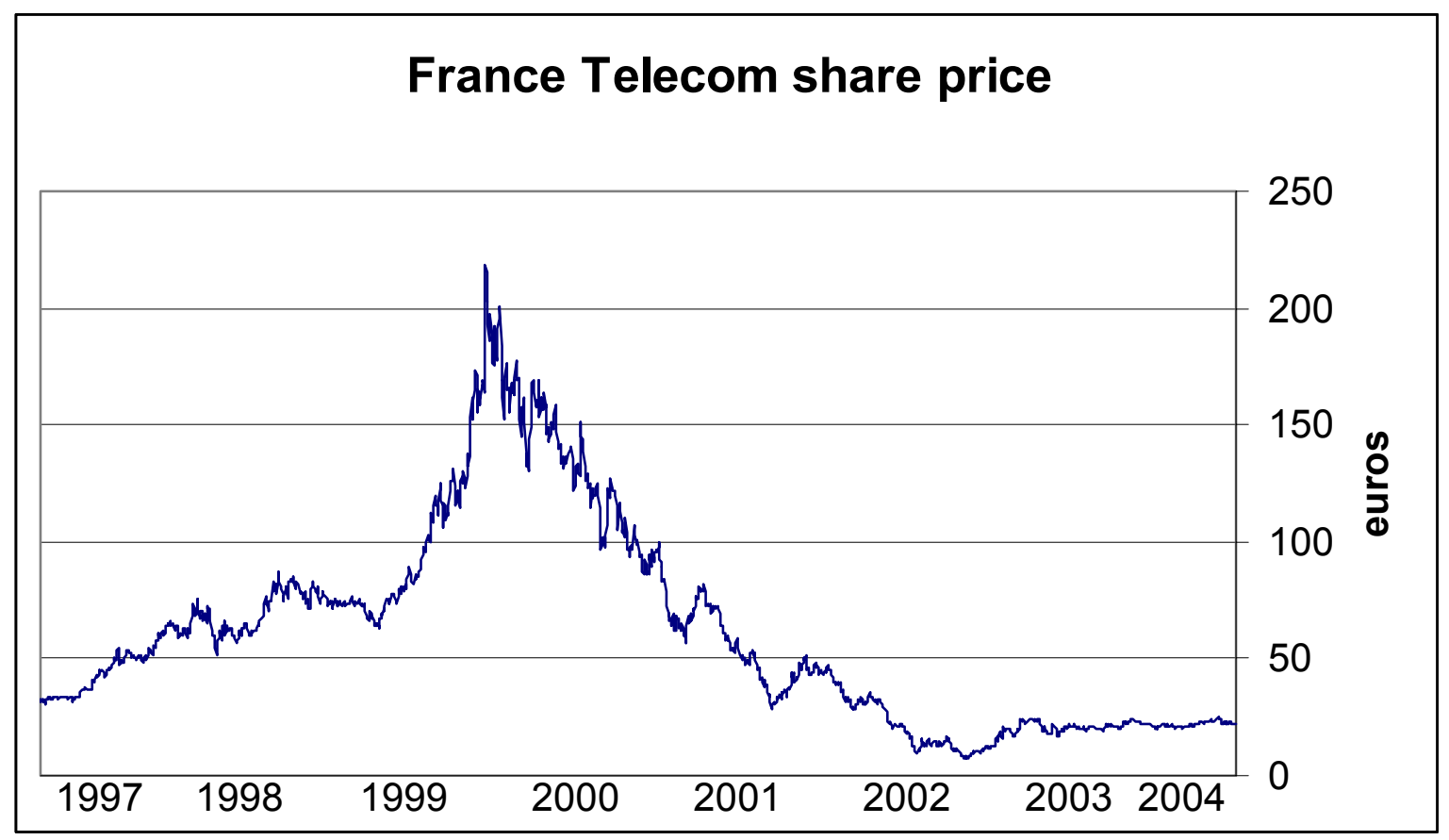


Table 1 - Public Firms Employment in France

\begin{tabular}{|c|c|c|c|}
\hline & $\begin{array}{c}\text { Employees } \\
\text { (thousands) }\end{array}$ & $\begin{array}{c}\text { \% of total wage } \\
\text { earners }\end{array}$ & $\begin{array}{c}\text { \% of total active } \\
\text { population }\end{array}$ \\
\hline 1947 & 1152 & 9.9 & 5.8 \\
\hline 1960 & 1108 & 8.3 & 5.6 \\
\hline 1970 & 970 & 6.0 & 4.5 \\
\hline 1980 & 1088 & 6.0 & 7.8 \\
\hline 1983 & 1852 & 10.3 & 5.6 \\
\hline 1988 & 1355 & 7.2 & 7.0 \\
\hline 1991 & $1763\left(^{*}\right)$ & 9.1 & 6.0 \\
\hline 1994 & 1505 & 7.7 & \\
\hline
\end{tabular}

Source: Chabanas and Vergeau (1996), based on figures provided by INSEE Note (*) In 1991, La Poste and France Telecom abandoned their administrative status and became state enterprises; this move added 430,000 employees to the total. 
Table 2 - Companies controlled by the state

\begin{tabular}{|c|c|c|c|}
\hline Year & $\begin{array}{c}\text { Number of } \\
\text { firms controlled }\end{array}$ & $\begin{array}{c}\text { Employees in France } \\
\text { (millions) }\end{array}$ & $\begin{array}{c}\text { Share of } \\
\text { Total wage } \\
\text { earners }\end{array}$ \\
\hline 2000 & 1500 & 1,1 & 5.3 \\
\hline
\end{tabular}

Source: INSEE, Répertoire des entreprises contrôlées majoritairement par l'Etat

Note: Table 1 and Table 2 figures cannot be compared due to changes in statistical methodology.

Table 3 - Privatization Framework

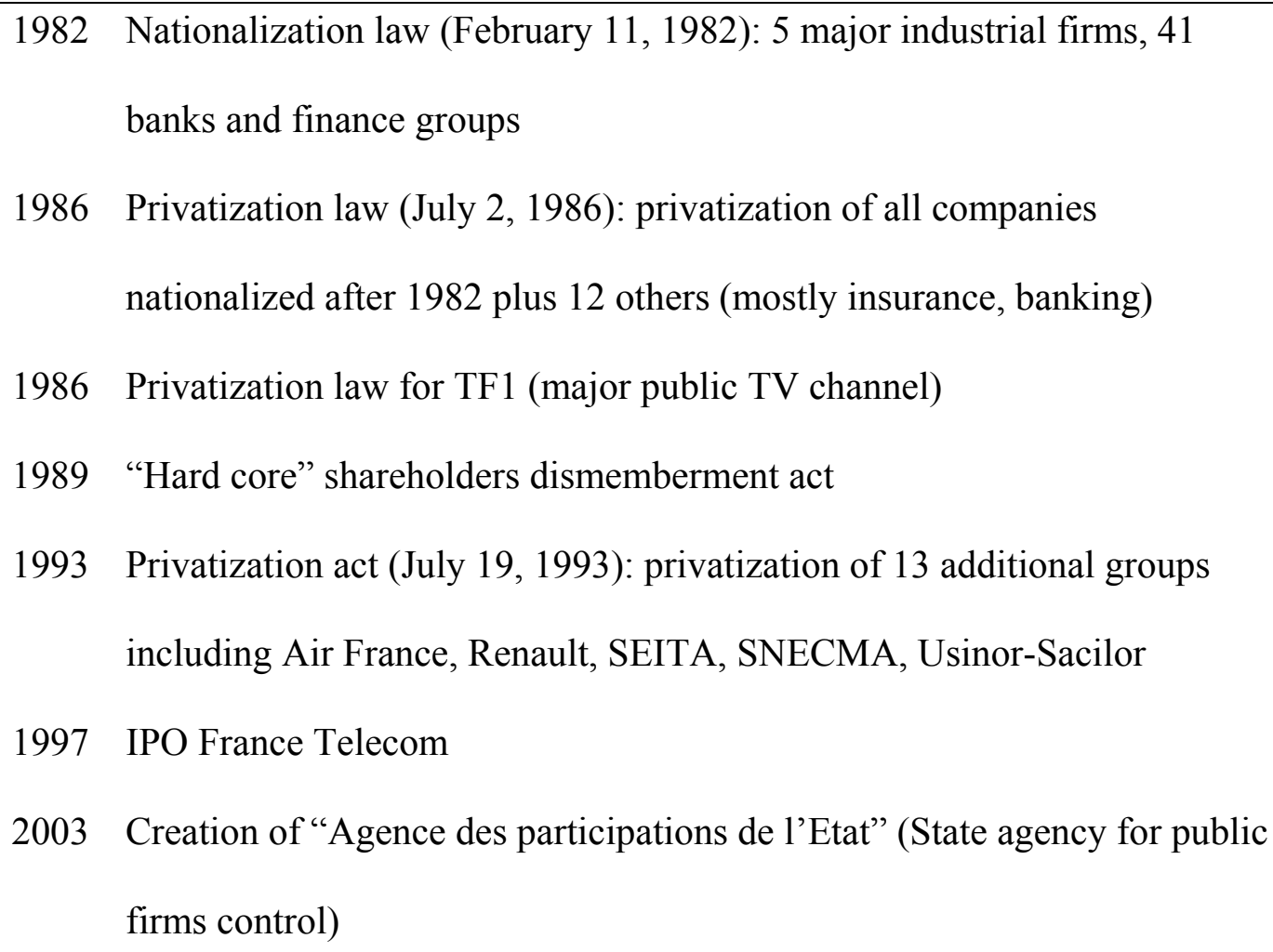

1986 Privatization law (July 2, 1986): privatization of all companies nationalized after 1982 plus 12 others (mostly insurance, banking)

1986 Privatization law for TF1 (major public TV channel)

1989 "Hard core" shareholders dismemberment act

1993 Privatization act (July 19, 1993): privatization of 13 additional groups including Air France, Renault, SEITA, SNECMA, Usinor-Sacilor

1997 IPO France Telecom

2003 Creation of "Agence des participations de l'Etat" (State agency for public firms control)

Source: adapted from Loiseau (2002) 
Table 4 - Major IPOs and sales of shares by the state

\begin{tabular}{|c|c|c|c|}
\hline Year & Industry & Services & Banking and Insurance \\
\hline 1986 & Saint-Gobain & & \\
\hline 1987 & $\begin{array}{l}\text { CGCT, } \\
\text { Compagnie Générale } \\
\text { d'Electricité }\end{array}$ & $\begin{array}{l}\text { TF1 } \\
\text { Havas }\end{array}$ & $\begin{array}{l}\text { Paribas, Compagnie financière } \\
\text { de Suez, Société Générale, } \\
\text { Crédit du Nord, CCF }\end{array}$ \\
\hline 1988 & Matra & & $\begin{array}{l}\text { Caisse nationale de crédit } \\
\text { agricole }\end{array}$ \\
\hline 1993 & Rhône-Poulenc & & $\mathrm{BNP}$ \\
\hline 1994 & Elf-Aquitaine & & $\begin{array}{l}\text { UAP, Société Lyonnaise de } \\
\text { Banque }\end{array}$ \\
\hline 1995 & $\begin{array}{l}\text { SEITA, Pechiney, } \\
\text { Usinor-Sacilor }\end{array}$ & & \\
\hline 1996 & & & AGF \\
\hline 1997 & Bull & France Telecom & \\
\hline 1998 & $\begin{array}{l}\text { Thomson-CSF (now } \\
\text { Thalès) }\end{array}$ & & CIC \\
\hline 1999 & Dassault & Air France & Crédit Lyonnais \\
\hline 2000 & $\begin{array}{l}\text { Thomson Multimedia, } \\
\text { EADS }\end{array}$ & & \\
\hline 2002 & & $\begin{array}{l}\text { Autoroutes du } \\
\text { Sud de la France }\end{array}$ & \\
\hline 2003 & Thomson & & \\
\hline
\end{tabular}




\begin{tabular}{|l|l|l|l|}
\hline & Dassault Systèmes & & \\
\hline
\end{tabular}

Source Loiseau 2002, Minefi 2003

Table 5 - Gross privatization income 1986-2002 - Major phases

\begin{tabular}{|c|c|c|c|}
\hline Government & Coalition in power & Dates & Income (billion $€$ ) \\
\hline Chirac & Right & $1986-1988$ & 13 \\
\hline Balladur & Right & $1993-1995$ & 17 \\
\hline Juppé & Right & $1995-1997$ & 9.4 \\
\hline Jospin & Left & $1997-2002$ & 31 \\
\hline
\end{tabular}

Note: more than $€ 6$ bn had been spent in 1983 in the major nationalization plan.

Source: Mauduit (2002) based on Baert (2000), Orange \& Rocco (1999) 
Table 6 - France Telecom Timeline

\begin{tabular}{|c|c|c|}
\hline Year & Regulation & France Telecom (FT) \\
\hline 1987 & European Green Book & \\
\hline 1990 & French post and telecom Acts & FT becomes a para-statal firm \\
\hline 1993 & $\begin{array}{l}\text { European decision: full competition } \\
\text { in } 1998\end{array}$ & $\begin{array}{l}\text { Alliance with Deutsche Telekom (Atlas) } \\
\text { Government decision to IPO FT }\end{array}$ \\
\hline 1995 & & CEO: Michel Bon \\
\hline 1996 & French telecom acts & $\begin{array}{l}\text { Alliance FT-Deutsche } \\
\text { Telekom-Sprint (Global One) }\end{array}$ \\
\hline 1997 & ART (regulatory agency) created & $\begin{array}{l}\text { FT becomes a private firm at year-end } \\
\text { Initial Public Offering }\end{array}$ \\
\hline 1998 & Full competition in Europe & $\begin{array}{l}\text { Pensions plans "returned" to the state } \\
\text { (bn5.7€) }\end{array}$ \\
\hline 1999 & & $2^{\text {nd }}$ tranche offered (FT) \\
\hline 2000 & UMTS auctions (UK, Germany) & $\begin{array}{l}\text { IPO, Wanadoo } \\
\text { Conflict with Deutsche Telekom; }\end{array}$ \\
\hline 2001 & & $\begin{array}{l}\text { Global One and Orange purchased } \\
\text { IPO, Orange }\end{array}$ \\
\hline 2002 & & Severe financial crisis \& bail-out; \\
\hline 2003 & & CEO: Thierry Breton \\
\hline & New European regulatory package & Full privatization of FT possible \\
\hline 2004 & $\begin{array}{l}\text { French telecom act } \\
\text { French telecom act }\end{array}$ & $\begin{array}{l}\text { Orange shares buy-out } \\
\text { Wanadoo shares buy-out }\end{array}$ \\
\hline
\end{tabular}


Table 7 - Shareholders of France Telecom

\begin{tabular}{|c|c|c|c|c|}
\hline$\%$ & Dec. 1997 & Jan. 1999 & Dec. 2002 & Sept. 2003 \\
\hline State (direct \& indirect) & 75 & 63.6 & 56.5 & 58.89 \\
\hline $\begin{array}{c}\text { General Public \& } \\
\text { Investors }\end{array}$ & 22.5 & 31.2 & 32.1 & 34.9 \\
\hline Owned by France \\
Telecom
\end{tabular}

Source: France Telecom 
Table 8 - Share of capital owned by foreign investors (2003)

\begin{tabular}{|c|c|c|c|c|}
\hline Firm & Sector & $\begin{array}{l}\text { Year of IPO or } \\
\text { privatization }\end{array}$ & $\begin{array}{l}\text { \% owned } \\
\text { by foreign } \\
\text { investors }\end{array}$ & $\begin{array}{l}\text { \% owned } \\
\text { by US } \\
\text { investors }\end{array}$ \\
\hline Vivendi (ex CGE) & Media & 1987 & 67.7 & 35.4 \\
\hline Total & Oil and gas & 1994 & 58.0 & 35.0 \\
\hline $\begin{array}{c}\text { Aventis (ex Rhône- } \\
\text { Poulenc) }\end{array}$ & Pharmacy & 1993 & 56.0 & 35.0 \\
\hline Alcatel (ex CGE) & Telecom equipment & 1987 & 50 & NA \\
\hline Saint-Gobain & Building materials & 1986 & 48 & 31 \\
\hline BNP Paribas & Bank & 1987 & 45 & NA \\
\hline Renault & Automobile & 1996 & 26 & NA \\
\hline Thomson & Electronics & 2000 & 20 & NA \\
\hline $\begin{array}{c}\text { Thales } \\
\text { (ex Thomson CSF) }\end{array}$ & Defense electronics & 1998 & 15 & NA \\
\hline France Telecom & $\begin{array}{c}\text { Telecommunication } \\
\text { s }\end{array}$ & 1997 & 11 & 3 \\
\hline TF1 & TV channel & 1987 & 28,1 & 12,5 \\
\hline
\end{tabular}

Note: France Telecom and TF1 figures for 2002. NA: not available

Source: Ducourtieux (2003), based on a survey conducted by Georgeson Shareholder 
Table 9 - Private shareholders in privatized companies

when the shares were sold

\begin{tabular}{|c|c|c|c|}
\hline Firm & Sector & Shareholders & Year \\
& & (millions) & \\
\hline France Telecom & telecommunications & 6.7 & $1997-1998$ \\
\hline Paribas & bank & 3.9 & 1986 \\
\hline Elf Aquitaine & oil \& gas & 3.5 & $1986-1994$ \\
\hline Rhône-Poulenc & chemicals \& drugs & 3.0 & 1993 \\
\hline BNP & bank & 2.8 & 1987 \\
\hline Air France & airline & 2.4 & \\
\hline Société Générale & bank & 2.3 & \\
\hline CGE (now & telecom equipment, & 2.3 & \\
Alcatel, Alstom & water distribution etc. & & \\
\& Vivendi) & & & \\
\hline
\end{tabular}

Source: SBF, Bourse de Paris in: (INSEE 1999 137). 
Table 10 - Sector Regulation in France - Main bodies

\begin{tabular}{|c|c|c|c|}
\hline & Sector & $\begin{array}{c}\text { Year } \\
\text { Created }\end{array}$ & Remarks \\
\hline $\begin{array}{l}\text { AMF } \\
\text { Autorité des } \\
\text { Marchés Financiers }\end{array}$ & Finance & 2003 & $\begin{array}{l}\text { Merger of the Commission } \\
\text { des Opérations de Bourse } \\
\text { and } 2 \text { other state bodies }\end{array}$ \\
\hline $\begin{array}{l}\text { ART } \\
\text { Autorité de } \\
\text { Régulation des } \\
\text { Télécommunications }\end{array}$ & Telecommunications & 1997 & $\begin{array}{c}\text { Independent regulatory } \\
\text { authority }\end{array}$ \\
\hline Banque de France & Banking & $\begin{array}{l}1800- \\
1993\end{array}$ & $\begin{array}{c}\text { Bank, } 100 \% \text { owned by the } \\
\text { state }\end{array}$ \\
\hline $\begin{array}{l}\text { CRE } \\
\text { Commission de } \\
\text { Régulation de } \\
\text { l'Energie }\end{array}$ & Electricity and gas & 2000 & $\begin{array}{l}\text { Regulator; the electricity } \\
\text { transport network (RTE) is } \\
\text { being separated from EdF, } \\
\text { the state-owned electricity } \\
\text { producer }\end{array}$ \\
\hline $\begin{array}{l}\text { CSA } \\
\text { Conseil Supérieur de } \\
\text { l'Audiovisuel }\end{array}$ & $\begin{array}{l}\text { Radio \& TV } \\
\text { broadcasting }\end{array}$ & 1989 & $\begin{array}{c}\text { Independent regulatory } \\
\text { authority }\end{array}$ \\
\hline $\begin{array}{l}\text { RFF } \\
\text { Réseau Ferré de } \\
\text { France }\end{array}$ & Railways & 1997 & $\begin{array}{l}\text { Regulator and owner of the } \\
\text { main railway network; } \\
\text { carries the network debt }\end{array}$ \\
\hline
\end{tabular}


Table 11 - Market share of new entrants - Telecommunications in France

\begin{tabular}{|c|c|c|c|c|c|c|c|}
\hline & 1996 & 1997 & 1998 & 1999 & 2000 & 2001 & 2002 \\
\hline $\begin{array}{l}\text { Long distance, fixed } \\
\text { (\% revenue) }\end{array}$ & - & - & 2.0 & 19.3 & 32.8 & 36.0 & 35.7 \\
\hline $\begin{array}{l}\text { Local, fixed } \\
\text { (\% revenue) }\end{array}$ & - & - & - & - & - & 3.2 & 19.1 \\
\hline Mobiles (\% users) & 42.1 & 47.0 & 50.5 & 51.3 & 51.8 & 51.9 & 50.0 \\
\hline ADSL (\% users) & - & - & - & - & - & 14 & 29 \\
\hline $\begin{array}{l}\text { Unbundled lines } \\
\text { (\% main lines) }\end{array}$ & - & - & - & - & - & 0.001 & 0.02 \\
\hline
\end{tabular}

Source: France Telecom Annual Reports; ART and calculations by the authors 
Table 12 - Major state-owned companies in France (2003)

\begin{tabular}{|c|c|c|c|c|}
\hline & Sector & $\begin{array}{c}\text { Sales (2002) } \\
\text { Billion } €\end{array}$ & $\begin{array}{c}\text { Profits (2002) } \\
\text { million } €\end{array}$ & $\begin{array}{c}\text { Employees } \\
(2002)\end{array}$ \\
\hline Air France & airline & 12.7 & 120 & 71500 \\
\hline Areva & nuclear industry & 8.3 & 240 & 50100 \\
\hline $\mathrm{DCN}$ & shipyard (Navy) & 2.2 & 118 & 13300 \\
\hline $\mathrm{EdF}$ & Electricity (utility) & 48.4 & 480 & 172000 \\
\hline France Télécom & telecommunications & 46.6 & $-20700 *$ & 240100 \\
\hline $\begin{array}{c}\text { France } \\
\text { Télévisions }\end{array}$ & Television channels & 2.3 & 53 & 6200 \\
\hline GdF & natural gas & 14.6 & 840 & 37900 \\
\hline GIAT & $\begin{array}{c}\text { army vehicles, } \\
\text { weapons }\end{array}$ & 0.8 & -118 & 6200 \\
\hline La Poste & postal services & 17.3 & 34 & 325000 \\
\hline SNECMA & aerospace & 6.5 & 106 & 39000 \\
\hline SNCF & railways & 22.2 & 63 & 182800 \\
\hline
\end{tabular}

* including -18.2 bn $€$ exceptional items (amortization and provisions)

Source: company information 
Table 13 - Privatization status of major state-controlled companies (2003)

\begin{tabular}{|c|c|c|c|}
\hline & $\begin{array}{l}\text { \% state- } \\
\text { owned }\end{array}$ & Status & Remarks \\
\hline Air France & 54 & $\begin{array}{l}\text { SA, on full } \\
\text { privatization track }\end{array}$ & $\begin{array}{c}\text { Government share below } 50 \% \text { when } \\
\text { Air France and KLM merge }\end{array}$ \\
\hline Areva & 95 & SA & $\begin{array}{l}\text { Part of the capital is held indirectly by } \\
\text { state entities (CEA, EdF) } \\
\text { The public cannot buy shares but } \\
\text { "investment certificates" }\end{array}$ \\
\hline $\mathrm{DCN}$ & 100 & SA since 2003 & Alliances being signed \\
\hline $\mathrm{EdF}$ & 100 & $\begin{array}{l}\text { EPIC, on } \\
\text { privatization track }\end{array}$ & Impacted by European deregulation \\
\hline GIAT & 100 & SA & $\begin{array}{l}\text { Evolution blocked due to poor financial } \\
\text { results }\end{array}$ \\
\hline $\begin{array}{l}\text { France } \\
\text { Télécom }\end{array}$ & 59 & SA & $\begin{array}{l}\text { Full privatization possible after new } \\
\text { law is adopted }\end{array}$ \\
\hline $\begin{array}{c}\text { France } \\
\text { Télévisions }\end{array}$ & 100 & SA & No official privatization plans \\
\hline $\mathrm{GdF}$ & 100 & $\begin{array}{l}\text { EPIC, on } \\
\text { privatization track }\end{array}$ & Impacted by European deregulation \\
\hline La Poste & 100 & "exploitant public" & Impacted by European deregulation \\
\hline SNECMA & 97.2 & $\begin{array}{c}\text { SA, on privatization } \\
\text { track }\end{array}$ & Planned for 2004 \\
\hline
\end{tabular}




\begin{tabular}{|c|c|c|c|}
\hline SNCF & 100 & EPIC & No privatization plans \\
\hline
\end{tabular}

Note: The normal legal status for large business firms in France is Société Anonyme (SA). SNCF, EdF and GdF are EPIC. The legal form of La Poste is unique but it is close to an EPIC.

Source: company information 
Table 14 - Residential prices - France Telecom

\begin{tabular}{|c|c|c|c|c|c|}
\hline $\begin{array}{l}\text { VAT included } \\
\text { Peak hours } \\
\text { Before any } \\
\text { discounts }\end{array}$ & $\begin{array}{c}1984 \\
\text { time/unit }\end{array}$ & $\begin{array}{c}1995 \\
\text { time/unit }\end{array}$ & $\begin{array}{c}1998 \\
\text { fixed charge }+ \\
\text { tariff/second }\end{array}$ & $\begin{array}{c}2000 \\
\text { fixed charge }+ \\
\text { tariff/second }\end{array}$ & $\begin{array}{c}2003 \\
\text { fixed charge }+ \\
\text { tariff/second }\end{array}$ \\
\hline $\begin{array}{l}\text { Local call } \\
\text { (3 minutes) }\end{array}$ & $\begin{array}{c}1 \text { unit/call } \\
0.098 €\end{array}$ & $\begin{array}{l}1 \text { unit/3 } \\
\text { minutes } \\
0.113 €\end{array}$ & $0.113 €$ & $0.157 €$ & $0.157 €$ \\
\hline $\begin{array}{l}\text { National call } \\
\text { (3 minutes) }\end{array}$ & $1.48 €$ & $1.02 €$ & $0.52 €$ & $0.36 €$ & $0.21 €$ \\
\hline $\begin{array}{l}\text { Monthly } \\
\text { access charge }\end{array}$ & $7.17 €(*)$ & $6.95 €$ & $10.37 €$ & $11.74 €$ & $13 €$ \\
\hline $\begin{array}{l}\text { Retail Price } \\
\text { Index }\end{array}$ & 100 & 137 & 143 & 146 & 154 \\
\hline
\end{tabular}

Note $\left(^{*}\right)$ : in 1984 , the monthly rental includes the supply of a telephone set 
Table 15 - Interconnection prices in France

\begin{tabular}{|l|c|c|c|c|c|c|}
\hline$€$ cent/minute & 1998 & 1999 & 2000 & 2001 & 2002 & 2003 \\
\hline Local & 0.928 & 0.707 & 0.667 & 0.616 & 0.579 & 0.5734 \\
\hline Simple transit & 1.948 & 1.537 & 1.356 & 1.252 & 1.051 & 1.0092 \\
\hline
\end{tabular}

Note : Average price for a basket of interconnection services

Source: ART 
Table 16 - Cost structure, France Telecom (selected items)

\begin{tabular}{|c|c|c|}
\hline $\begin{array}{l}\text { Million } € \\
\% \text { of sales }\end{array}$ & 1996 & 2002 \\
\hline Sales & $\begin{array}{l}23059 \\
100 \%\end{array}$ & $\begin{array}{l}46630 \\
100 \%\end{array}$ \\
\hline Personnel costs & $\begin{array}{l}6664 \\
29 \%\end{array}$ & $\begin{array}{l}10240 \\
22 \%\end{array}$ \\
\hline Commercial and administrative costs & $\begin{array}{l}5046 \\
22 \%\end{array}$ & $\begin{array}{l}12579 \\
27 \%\end{array}$ \\
\hline$R \& D$ costs & $\begin{array}{c}820 \\
3.6 \%\end{array}$ & $\begin{array}{c}576 \\
1.2 \%\end{array}$ \\
\hline Financial costs (net) & $\begin{array}{c}814 \\
3.5 \%\end{array}$ & $\begin{array}{l}4041 \\
8.7 \%\end{array}$ \\
\hline Income Tax & $\begin{array}{l}702 \\
3.0 \%\end{array}$ & $\begin{array}{l}2499 \\
5.3 \%\end{array}$ \\
\hline Net income & $\begin{array}{l}321 \\
9.1 \%\end{array}$ & $\begin{array}{l}-20736 \\
-44.5 \%\end{array}$ \\
\hline
\end{tabular}

Source : France Telecom Annual Reports 
Table 17 - Labor productivity, France Telecom in France

\begin{tabular}{|l|c|c|c|c|c|}
\hline & Employees & Fixed lines & Mobile & TV cable & Internet \\
& & (thousands) & lines & (thousand & (thousand \\
& & & (thousands) & lines) & customers) \\
\hline 1996 & 160700 & 33200 & 1560 & 663 & 18 \\
\hline 1997 & 155500 & 33700 & 3081 & 705 & 106 \\
\hline 1998 & 155000 & 34000 & 5450 & 754 & 495 \\
\hline 1999 & 152300 & 34056 & 10051 & 709 & 1016 \\
\hline 2000 & 148900 & 34114 & 14311 & 769 & 1831 \\
\hline 2001 & 145300 & 34151 & 17823 & 824 & 3001 \\
\hline 2002 & 141100 & 34066 & 19216 & 854 & 3924 \\
\hline
\end{tabular}

Source : France Telecom Annual Reports, calculations by the authors 
Table 18 - Return for investors, selected privatized companies

\begin{tabular}{|l|c|c|c|c|}
\hline Company & IPO date & $\begin{array}{c}\text { Initial stock price } \\
€\end{array}$ & $\begin{array}{c}\text { Adjusted stock price, } \\
\text { 31-10-2003, } €\end{array}$ & \\
\hline BNP & 1993 & 18.30 & 45.6 & 147 \\
\hline Renault & 1993 & 25.15 & 56.9 & 126 \\
\hline Usinor-Sacilor & 1995 & 13.11 & 12.3 & -6 \\
\hline Bull & 1997 & 5.49 & 0.80 & -84 \\
\hline Thomson Multimedia 1 & 1999 & 10.73 & 18.10 & -66 \\
\hline Thomson Multimedia 2 & 2000 & 53.90 & 20.08 & -13 \\
\hline France Telecom 1 & 1997 & 24.03 & 20.8 & -60 \\
\hline France Telecom 2 & 1998 & 51.59 & 6.4 & 0 \\
\hline Wanadoo & 2000 & 19.00 & 9.5 & \\
\hline Orange & 2001 & 9.5 & & \\
\hline
\end{tabular}

Source: Figaro, 2003 
Table 19 - France Telecom at a glance

\begin{tabular}{|c|c|c|c|c|c|c|c|}
\hline & 1996 & 1997 & 1998 & 1999 & 2000 & 2001 & 2002 \\
\hline $\begin{array}{l}\text { Group turnover } \\
\text { (bn€) }\end{array}$ & 22.9 & 23.4 & 24.6 & 27.2 & 33.7 & 43.0 & 46.6 \\
\hline $\begin{array}{l}\text { Profit } \\
\text { (bn€) }\end{array}$ & 0.3 & 2.3 & 2.3 & 2.8 & 3.7 & -8.3 & -20.7 \\
\hline $\begin{array}{l}\text { Long-term } \\
\text { debt (bn€) }\end{array}$ & 16.3 & 15.4 & 13.1 & 14.6 & 61.0 & 60.7 & 68 \\
\hline $\begin{array}{l}\text { Employees } \\
\text { (Group) }\end{array}$ & 164,700 & 165,000 & 169,100 & 174,300 & 188,900 & 206,200 & 240,100 \\
\hline $\begin{array}{l}\text { Employees } \\
\text { (France) }\end{array}$ & 160,700 & 155,500 & 155,000 & 152,300 & 148,900 & 145,300 & 141,100 \\
\hline $\begin{array}{l}\text { Fixed -France } \\
\text { ( } \% \text { of sales) }\end{array}$ & 88 & 82 & 77 & 70 & 55 & 46 & 40 \\
\hline $\begin{array}{l}\text { Fixed }- \text { abroad } \\
(\% \text { of sales })\end{array}$ & 1 & 2 & 3 & 9 & 16 & 16 & 20 \\
\hline $\begin{array}{l}\text { Mobiles } \\
\text { ( } \% \text { of sales) }\end{array}$ & 7 & 11 & 15 & 17 & 26 & 34 & 36 \\
\hline $\begin{array}{l}\text { Internet / } \\
\text { (\% of sales) }\end{array}$ & 4 & 5 & 5 & 3 & 3 & 4 & 4 \\
\hline
\end{tabular}

Source: France Telecom, Annual Reports and calculations by the authors

Internet sales include videotex and directories revenues 


\section{CESifo Working Paper Series}

(for full list see www.cesifo.de)

1132 David M. Newbery, Privatising Network Industries, February 2004

1133 Charles Yuji Horioka, The Stagnation of Household Consumption in Japan, February 2004

1134 Eiji Fujii, Exchange Rate Pass-Through in the Deflationary Japan: How Effective is the Yen's Depreciation for Fighting Deflation?, February 2004

1135 Mark M. Spiegel and Nobuyoshi Yamori, Determinants of Voluntary Bank Disclosure: Evidence from Japanese Shinkin Banks, Febrary 2004

1136 Robert Dekle and Kenneth Kletzer, Deposit Insurance, Regulatory Forbearance and Economic Growth: Implications for the Japanese Banking Crisis, February 2004

1137 Takatoshi Ito and Kimie Harada, Bank Fragility in Japan, 1995-2003, February 2004

1138 Kunio Okina and Shigenori Shiratsuka, Policy Duration Effect under Zero Interest Rates: An Application of Wavelet Analysis, February 2004

1139 Francine D. Blau and Lawrence M. Kahn, Do Cognitive Test Scores Explain Higher U.S. Wage Inequality?, February 2004

1140 Michael Rauscher, Economic Growth and Tax-Competing Leviathans, February 2004

1141 Ernst Fehr and Jean-Robert Tyran, Money Illusion and Coordination Failure, February 2004

1142 Ingo Vogelsang, Network Utilities in the U.S. - Sector Reforms without Privatization, March 2004

1143 Marc-Andreas Muendler, Estimating Production Functions When Productivity Change is Endogenous, March 2004

1144 Sascha O. Becker, Samuel Bentolila, Ana Fernandes, and Andrea Ichino, Job Insecurity and Children's Emancipation, March 2004

1145 Pascalis Raimondos-Møller and Alan D. Woodland, Non-Preferential Trading Clubs, March 2004

1146 Robert Fenge and Matthias Wrede, EU Regional Policy: Vertical Fiscal Externalities and Matching Grants, March 2004

1147 Chi-Yung Ng and John Whalley, Geographical Extension of Free Trade Zones as Trade Liberalization: A Numerical Simulation Approach, March 2004 
1148 Marc-Andreas Muendler, Trade, Technology, and Productivity: A Study of Brazilian Manufacturers, 1986-1998, March 2004

1149 Eugene Beaulieu, Vivek H. Dehejia, and Hazrat-Omar Zakhilwal, International Trade, Labour Turnover, and the Wage Premium: Testing the Bhagwati-Dehejia Hypothesis for Canada, March 2004

1150 Giorgio Brunello and Francesca Gambarotto, Agglomeration Effects on EmployerProvided Training: Evidence from the UK, March 2004

1151 S. Brock Blomberg, Gregory D. Hess, and Athanasios Orphanides, The Macroeconomic Consequences of Terrorism, March 2004

1152 Bodo Sturm and Joachim Weimann, Unilateral Emissions Abatement: An Experiment, March 2004

1153 Wolfgang Ochel, Welfare-to-Work Experiences with Specific Work-First Programmes in Selected Countries, March 2004

1154 Jan K. Brueckner and Eric Pels, European Airline Mergers, Alliance Consolidation, and Consumer Welfare, March 2004

1155 Aaron Tornell, Frank Westermann, and Lorenza Martínez, NAFTA and Mexico's Economic Performance, March 2004

1156 George Economides, Sarantis Kalyvitis, and Apostolis Philippopoulos, Do Foreign Aid Transfers Distort Incentives and Hurt Growth? Theory and Evidence from 75 Aid-recipient Countries, March 2004

1157 Robert Fenge and Volker Meier, Are Family Allowances and Fertility-related pensions Siamese Twins?, March 2004

1158 Bruno S. Frey, Simon Luechinger, and Alois Stutzer, Valuing Public Goods: The Life Satisfation Approach, March 2004

1159 Jerome L. Stein and Guay C. Lim, Asian Crises: Theory, Evidence, Warning-Signals, March 2004

1160 Romain Ranciere, Aaron Tornell, and Frank Westermann, Crises and Growth: A ReEvaluation, March 2004

1161 Assaf Razin and Efraim Sadka, Transparency, Specialization and FDI, March 2004

1162 Ludger Woessmann, How Equal Are Educational Opportunities? Family Background and Student Achievement in Europe and the United States, March 2004

1163 B.M.S. van Praag and Barbara E. Baarsma, Using Happiness Surveys to Value Intangibles: The Case of Airport Noise, March 2004

1164 Aaron Tornell, Frank Westermann, and Lorenza Martínez, The Positive Link Between Financial Liberalization, Growth, and Crises, March 2004 
1165 Helge Berger and Carsten Hefeker, One Country, One Vote? Labor Market Structure and Voting Rights in the ECB, March 2004

1166 Clemens Fuest and Martin Kolmar, A Theory of User-Fee Competition, March 2004

1167 Friedrich Schneider and Robert Klinglmair, Shadow Economies around the World: What Do We Know?, April 2004

1168 Horst Raff and Nicolas Schmitt, Exclusive Dealing and Common Agency in International Markets, April 2004

1169 M. Hashem Pesaran and Allan Timmermann, Real Time Econometrics, April 2004

1170 Sean D. Barrett, Privatisation in Ireland, April 2004

1171 V. Anton Muscatelli, Patrizio Tirelli and Carmine Trecroci, Can Fiscal Policy Help Macroeconomic Stabilisation? Evidence from a New Keynesian Model with Liquidity Constraints, April 2004

1172 Bernd Huber and Marco Runkel, Tax Competition, Excludable Public Goods and User Charges, April 2004

1173 John McMillan and Pablo Zoido, How to Subvert Democracy: Montesinos in Peru, April 2004

1174 Theo Eicher and Jong Woo Kang, Trade, Foreign Direct Investment or Acquisition: Optimal Entry Modes for Multinationals, April 2004

1175 Chang Woon Nam and Doina Maria Radulescu, Types of Tax Concessions for Attracting Foreign Direct Investment in Free Economic Zones, April 2004

1176 M. Hashem Pesaran and Andreas Pick, Econometric Issues in the Analysis of Contagion, April 2004

1177 Steinar Holden and Fredrik Wulfsberg, Downward Nominal Wage Rigidity in Europe, April 2004

1178 Stefan Lachenmaier and Ludger Woessmann, Does Innovation Cause Exports? Evidence from Exogenous Innovation Impulses and Obstacles, April 2004

1179 Thiess Buettner and Johannes Rincke, Labor Market Effects of Economic Integration The Impact of Re-Unification in German Border Regions, April 2004

1180 Marko Koethenbuerger, Leviathans, Federal Transfers, and the Cartelization Hypothesis, April 2004

1181 Michael Hoel, Tor Iversen, Tore Nilssen, and Jon Vislie, Genetic Testing and Repulsion from Chance, April 2004 
1182 Paul De Grauwe and Gunther Schnabl, Exchange Rate Regimes and Macroeconomic Stability in Central and Eastern Europe, April 2004

1183 Arjan M. Lejour and Ruud A. de Mooij, Turkish Delight - Does Turkey's accession to the EU bring economic benefits?, May 2004

1184 Anzelika Zaiceva, Implications of EU Accession for International Migration: An Assessment of Potential Migration Pressure, May 2004

1185 Udo Kreickemeier, Fair Wages and Human Capital Accumulation in a Global Economy, May 2004

1186 Jean-Pierre Ponssard, Rent Dissipation in Repeated Entry Games: Some New Results, May 2004

1187 Pablo Arocena, Privatisation Policy in Spain: Stuck Between Liberalisation and the Protection of Nationals' Interests, May 2004

1188 Günter Knieps, Privatisation of Network Industries in Germany: A Disaggregated Approach, May 2004

1189 Robert J. Gary-Bobo and Alain Trannoy, Efficient Tuition Fees, Examinations, and Subsidies, May 2004

1190 Saku Aura and Gregory D. Hess, What's in a Name?, May 2004

1191 Sjur Didrik Flåm and Yuri Ermoliev, Investment Uncertainty, and Production Games, May 2004

1192 Yin-Wong Cheung and Jude Yuen, The Suitability of a Greater China Currency Union, May 2004

1193 Inés Macho-Stadler and David Pérez-Castrillo, Optimal Enforcement Policy and Firms' Emissions and Compliance with Environmental Taxes, May 2004

1194 Paul De Grauwe and Marianna Grimaldi, Bubbles and Crashes in a Behavioural Finance Model, May 2004

1195 Michel Berne and Gérard Pogorel, Privatization Experiences in France, May 2004 